\title{
The Cross-Pressure of Flannery O'Connor
}

\author{
by
}

Christopher Jenkins

A thesis submitted to the Faculty of Graduate and Postdoctoral Affairs in partial fulfillment of the requirements for the degree of

Master of Arts

in

English

Carleton University

Ottawa, Ontario

(C) 2013 
This thesis examines Charles Taylor's concept of "cross-pressure" as illustrated in Flannery O'Connor's two novels, Wise Blood and The Violent Bear It Away. In A Secular Age, Taylor argues that ever since the emergence of "exclusive humanism" humanity has been forced to inhabit an "open space" in which the "cross-pressure" of world views has characterized its experience and rendered any form of "naïve faith" impossible. This thesis will illustrate how O'Connor's novels reflect this "open space" and the "crosspressure" with which it is assailed, subjecting characters and reader alike to a fundamental ambiguity concerning the structure of reality. Accordingly, it will argue against the situating of O'Connor's work strictly within the limits of grotesque realism and in favor of situating it on the border of the grotesque and the fantastic, this latter being characterized as obliging the reader "to hesitate between a natural and supernatural explanation of the events described". By subjecting characters and reader alike to this fundamental ambiguity, O'Connor is able to realistically depict the dilemma of faith in a secular age. 
I would like to thank my thesis supervisor, Travis DeCook, for all of his guidance and encouragement and for the many interesting conversations we had over the past year. I would like to thank Maxime Allard from the Dominican University College for getting me to read A Secular Age and for doing his very best to teach an English student about metaphysics and the genius of Thomas Aquinas. I would like to thank my Graduate Supervisor, Barbara Leckie, for helping to facilitate the course of study that made this thesis possible. I would like to thank Pat Whiting for lending me a copy of O'Connor's collected letters for well over a year. They were truly a gold mine! I would like to thank the professors who have encouraged me over the years, especially Sarah Brouillette, Thomas Steffler, and Matthew Brillinger. Last but not least, I would like to thank my beautiful wife, Elizabeth, as well as members of my immediate and extended family, for their untiring love and support.

Chris Jenkins, 2013 


\section{Table of Contents}

Chapter

1.

2.
Title

Introduction: Flannery O'Connor and A Secular Age

Freud, Fundamentalism and the Fantastic

Out of Nihilism?

Conclusion: Cross-Pressure and the Pressure of the Cross

Works Cited
Page

1

8

38

65

71 
Introduction: Flannery O'Connor and A Secular Age

There has been no shortage of Flannery O'Connor critics to have addressed the clashing of world views which informs much of her work. For instance, in Return to Good and Evil, Henry T. Edmondson III analyzes O'Connor's work as a response to twentieth-century nihilism which clearly and unambiguously advocates a return to a moral Christian heritage. Similarly, in The True Country, Carter W. Martin attributes to O'Connor's fiction a "sacramental view of life" (9) necessarily at odds with secular modernity. While all the above may be true, as literary criticism such readings stray too far outside the text, relying far too heavily upon O'Connor's letters and non-fictional writings as well as her personal beliefs in order to identify meaning. Furthermore, this is something of which O'Connor did not approve. In an essay entitled "The Teaching of Literature," O'Connor writes, "a work of art exists without its author from the moment the words are on paper, and the more complete the work, the less important it is who wrote it or why" (126). When the "who" and the "why" are omitted from consideration, and critical analysis focuses on the texts themselves, O'Connor's vision as embodied in her fiction becomes far more ambiguous than such critics would have it.

While such a leveling tendency clearly exists in O'Connor studies, some critics have duly noted the ambiguity that pervades much of her work. Joseph Zorando, for instance, writes, "Much of Flannery O'Connor's fiction undermines the notion that her texts, or any text for that matter, offers the reader a chance at fixed comprehensibility" (27). He continues, "O'Connor's fiction often clears itself away as a meaning-bearing icon in 
order to introduce the reader to something other, to the mystery latent and invisible in the manners" (27). This thesis will proceed from the assumption that this "mystery" which takes the form of a fundamental ambiguity within O'Connor's fictional vision is not only intentional but essential to the realistic portrayal of the dilemma of faith in a secular age, a dilemma which O'Connor has characterized as her "ultimate concern"” (HOB 221). In this way, it will seek to establish a relation between this fundamental ambiguity and the " "ultimate concern"” she has so ardently identified in her personal correspondence and other non-fictional writings. Any comments made by O'Connor in these writings which clarify the central ambiguities of her novels will, however, not be considered until the concluding remarks. Using key concepts from Charles Taylor's theorization of secularity, this thesis will illustrate how O'Connor's work, far from offering the reader the assurance of a definite world view, situates characters and readers alike in an ambiguous "open space" (Taylor 549) that demands a response of faith. It is my hope that, accordingly, it will respond to the challenge of one critic to all future O'Connor scholars, "to be generative rather than mummifying" through "deepen[ing] the awareness of mystery in her work" (Donahoo 243), thereby avoiding a stale religious reading without ignoring the fact that O’Connor is, first and foremost, a religious writer.

In Partial Faiths, John McClure situates what he calls "Post secular religiosity" (17) as existing between the absolutist meta-narratives of "conventional monotheism" and "secular humanism" (15). According to McClure, "Faith in such a context can only be partial, anxious, uncertain" (33). The dialectic McClure seems to envision is thus a movement from the dogmatic certitude of Christendom to an equally dogmatic certitude in secular humanism and its god of reason and finally to a "weakened religiosity [...] 
emerging on the frontier between sacred and secular systems of belief' (14). In doing so, McClure depicts a one-dimensional secular age that fails to incorporate the complexities and ambiguities by which it is truly characterized. In all likelihood there is no such thing as a postsecular age. Rather, what McClure is actually describing is the secular age proper as experienced by many. Amy Hungerford, who is far more careful in her use of terms, preferring "postmodern" (7) to McClure's "postsecular," writes that, "the secular age in which we live" is "an age in which one can no longer maintain religious belief without the simultaneous knowledge that others do not believe" (xiv my emphasis). While O'Connor captures this experience of living in a disenchanted secular age through fiction, it is philosophically elucidated by Charles Taylor.

In A Secular Age, Charles Taylor explores secularity in terms of the changed “conditions of belief" (3). His book attempts to outline the changes that have taken place in Western European culture from the late middle ages when a belief in God was "axiomatic" (3) to the present day in which such a belief merely represents one option among many, and one that is often increasingly difficult to defend both to oneself and to others. The movement he envisions is thus a movement from a "naïve" to a "reflexive" faith (13). This means that whereas once it was possible to "live "naively' in a construal," this is no longer the case (12). By "construal" Taylor means "world view," and what he is getting at is that in the "naïve" dispensation there was no such awareness that one possessed a "world view". Rather, what we, speaking within the "reflexive" age, refer to as a "world view," such as the belief that God exists and plays an active role in the salvation of mankind, was simply a given of experience, something to be taken for granted. Heidegger seems to be saying a similar thing when in an essay entitled, "The 
Age of The World Picture," he refers to the "impossibility," and indeed, the "absurdity," of the very notion of a medieval or Catholic "world view" (221). The notion of "world view" is thus something unique to modernity, placing modern humanity in a very different position in relation to the world than his medieval predecessors. Taylor accordingly sees modern humanity as having to navigate between two standpoints, "an 'engaged' one in which we live as best we can the reality our standpoint opens us to; and a 'disengaged' one in which we are able to see ourselves as occupying one standpoint among a range of possible ones" (12). In other words, modern humanity is "reflexive," that is, self-consciously possessing of a "world view". And it is not merely the religious believer who is in this predicament, but indeed, the atheist as well. One cannot be a "naïve" atheist, unaware that other valid world views exist, some of which contradict one's own. We are all “cross-pressured” (302), to use one of Taylor's helpful terms.

The factors Taylor sees as contributing to this change are manifold and beyond the scope of this thesis to address. The major pivotal changes which must be noted are the "anthropocentric shift" (221) Taylor views as occurring during the period of the Enlightenment and the "exclusive humanism" (230) that thereby emerges. It is the emergence of this "exclusive humanism" as the previously unthinkable possibility of conceiving of human fullness without reference to any transcendent "ultimate reality" (2) that Taylor views as having engendered a "nova" (300) of proliferating world views. What must be noted, in response to McClure's one-dimensional picture of secularity, is that in Taylor's depiction "exclusive humanism" is but one possibility amongst others rather than the dogmatic correlate to Christendom. Heidegger expresses a similar vision to that of Taylor's when he writes, “the ever more exclusive rooting of the interpretation 
of the world in anthropology, which has set in since the end of the eighteenth century, finds expression in the fact that humans' fundamental relation to beings as a whole is defined as a world view," and thus describes the metaphysics of modernity as "a confrontation of world views" (221). While Heidegger sees this "relation to beings as whole" as inseparable from the objectifying science of modernity, Taylor sees it as inseparable from the "buffered- self" of "disengagement" (42). But, of course, these are simply the objective and subjective poles of one epistemological posture, as Heidegger alludes to when he writes, "[w]hat is essential here is the necessary interplay between subjectivism and objectivism" (217). In other words, an objectification of "beings as a whole" into a "world view" is one with an anthropocentric positing of the subject as ultimate reference point.

Thus, an "anthropocentric shift," which entails a subjective stance of disengagement correlating to an instrumental objectification of "beings as a whole," places modern man in a nova of proliferating world views in which the winds of "cross pressure" ever blow him hither and yon. While this description evokes an image of chaos, of schizophrenic disorientation, and while this may, in fact, be somewhat characteristic of modernity, especially in its post-modern phase, Taylor does view Westerners, in general, as sharing an underlying frame work which gives shape and coherence to their world and which he refers to as the "immanent frame" (542). Essentially, the "immanent frame" follows from "exclusive humanism" and the religious reforms from which it emerged, all of which diminished the presence of the transcendent in social consciousness. Taylor thus refers to an "immanentization" (257) occurring over the course of centuries through which humanity's values and goals come to be defined more and more in immanent terms, ever 
catering to "the buffered identity of the disciplined individual" and his "instrumental rationality" (542). Thus, even the Christianity which has survived the upheavals of modernity must exist within this "immanent frame".

Taylor sees two main ways of existing within this "immanent frame," one which leaves it "open" and one in which it is effectively "closed" (543-44). Of this latter option, there are two variants. One variant is that in which the possibility of the transcendent is “slough[ed] off" (543), a view Taylor sees as characteristic of the academic hegemony (549). The other way in which the "immanent frame" can be lived as closed is by similarly "spinning" (550) it into what Taylor refers to as a "closed world structure" (551), only in this case it is not the possibility of the transcendent that is omitted, but rather the possibility of its impossibility. But whether academic intellectual or Christian fundamentalist, this attempt at closure is ultimately an attempt to avoid the winds of “cross pressure," to avoid having to stand in what Taylor, in an allusion to William James, refers to as the "Jamesian open space" in which one feels "some of the force of each opposing position" (549). According to Taylor, such attempts at "closure" necessitate a certain level of intellectual dishonesty and willful blindness (550). To live the "immanent frame" as open, conversely, means to experience the opposition of both closed "spins," to dwell in that "open space," and yet to realize that to go in either direction necessitates a "leap of faith," based on an "anticipatory confidence" (550) at best, but never the assurance that would attempt to make of belief or unbelief certain knowledge.

Focusing on her two novels, Wise Blood and The Violent Bear It Away, this thesis will argue that the work of Flannery O'Connor reflects this "open space" and the "cross 
pressure" with which it is assailed. It does so both at the level of the characters and that of the reader so that the ambiguity faced by the former is likewise experienced by the latter. As such, it will argue against the prevalent situating of O'Connor's oeuvre within the limits of grotesque realism and in favor of a reading that situates her as straddling the borders of the grotesque and the fantastic, this latter being characterized as obliging the reader to "hesitate between a natural and a supernatural explanation of the events described" (Todorov 33). In The Violent Bear It Away, the "cross pressure" which the central protagonist must negotiate is that between a Christian fundamentalist world view and a scientific humanism which, in a Freudian manner, interprets the call to religious vocation as a pathological form of self-deception. In Wise Blood, the "open space" is saturated with the uncanniness of nihilism, it being both that which is overcome and that which overcomes. In both novels, while the central protagonists arrive at a resolution of sorts, the reader is left hesitating, caught in the winds of "cross pressure," left to dwell in the "open space," or to take a leap of faith in one direction or the other. Though Wise Blood is chronologically antecedent to The Violent Bear It Away, the latter will be dealt with first as it presents a clearer representation of the concepts involved and will facilitate a firmer understanding the better to elucidate the ins and outs of the second and, by far, denser text. 
Freud, Fundamentalism and the Fantastic

In The Violent Bear It Away, as in some of her other stories, Flannery O'Connor opposes the country and the city as sites where very different world views prevail, the former generally being associated with backwoods religious fundamentalism and the latter with the so-called march of reason and progress. Through the partiality of her characters O'Connor's narrator reveals the inner dynamics of these world views, but every objective event described in the text can be interpreted according to either. Thus, the metaphysical reality that underlies the fictional world of the novel is always in question. The reason for this central ambiguity is that at the respective poles of this spectrum of belief/unbelief a "closed world structure" circumscribes a reality which includes its polar opposite within the overall context of its meaning. Each represents an attempt to sustain a "naïve" faith, whether in belief or unbelief, in the face of its alternative, largely through a process of rationalization and denial. The impossibility of sustaining this naivety represents the dramatic tension of the text as the central characters are driven by the winds of "cross pressure" out into the "open space" of a metaphysical disorientation that is particularly characteristic of a secular age. They arrive at their resolutions through acts of faith, thus leaving the implied reader, who inhabits the "immanent frame" of the same secular age, to interpret these resolutions and the reality that they suggest according to his or her own similar act.

The clearing at Powderhead is the backwoods site where Francis Marion Tarwater lived with his great uncle, Mason, and where the latter attempted to raise the former according to the dictates of his own "naïve" faith. On the first page we read, "His [great] 
uncle had taught him Figures, Reading, Writing, and History beginning with Adam expelled from the Garden and going on down through the presidents to Herbert Hoover and on in speculation toward the Second Coming and the Day of Judgement" (O'Connor TVBIA 331). The man who imparted this knowledge did not view Christian teleology as one world view amongst others to which he could or could not subscribe, but rather as a historical reality of the same ontological status as the American presidency. Joseph Zorando thus, quite aptly, refers to Tarwater's "religious training" as being "imbued with the maniacal zeal of his great-uncle complemented by a storybook literalness" (45). Powderhead, the locus of this "literal," or biblically based "naïve" faith, having once belonged to Mason's father, represents the faith of one's fathers. At the age of eighteen, Mason's sister ran away from Powderhead to the city and there married an insurance salesman, soon giving birth to Rayber and his sister, Tarwater's mother. Whether or not her running away signified an outright rejection of the faith of her fathers, in the city she soon grew indifferent to it. Thus the central polarity of the text is established, opening an ambiguous "open space" which the next generations are forced to inhabit. This is foreshadowed in the first sentence of the text which announces Mason's death and, consequently, the death of the "naive" faith he represents. Though Mason, and the faith he lived by, continue to influence the living characters in the text, it is only in the form of "cross-pressure" within the "open space".

The first to feel the brunt of the "cross-pressure" this schism engendered was Mason's nephew, Rayber. Jason Peters argues that Rayber, as a grown man, is typical of the "machine age" and the "abstraction" which is its "besetting malady" (89). While this may be true, it must be noted that "abstraction" is simply another term for the 
"disengagement" that both Taylor and Heidegger view as essential to the epistemological stance of secular modernity. The source of Rayber's abstracted, or "reflexive", mode of being must thus be sought in the metaphysical "cross-pressure" which he experienced as a child. With his mother locked away in her bedroom sinking into drunken dissolution and his father away on business, Mason took it upon himself to kidnap the child of seven, taking him back to Powderhead where he at once "baptized him and instructed him in the facts of his Redemption" (O'Connor TVBIA 333). That the term "facts" is used in this regard is further indicative of the "naivety" of Mason's faith:

In four days the old man taught him what was necessary to know and baptized him. He made him understand that his true father was the Lord and not the simpleton in town and that he would have to lead a secret life in Jesus until the day came when he would be able to bring the rest of his family around to repentance. [...] Since this was the first time anybody had bothered to tell these facts to the schoolteacher [Rayber], he could not hear too much of them and as he had never seen woods before or been in a boat or caught a fish or walked on roads that were not paved, they did all those things too (371).

The impression is that a new world suddenly became apparent to Rayber, a world in many ways in contradistinction to the one he had always known. Mason was thus quite correct in believing, upon Rayber's departure from Powderhead, that "he would never be the same boy again" (371), though perhaps not in the way in which the former imagined.

At fourteen, Rayber returned to Powderhead, having decided that "none of it was true" (371) and wanting to proclaim it. We read that "his daddy told him the old man was crazy and not to believe a word of what all he had learnt him" (355). Mason thus claimed, “ $\mathrm{He}$ 
was living in confusion. I don't say it was his fault then. They told him I was a crazy man. But I'll tell you one thing: he never believed them neither. They kept him from believing me but I kept him from believing them"' (372). This last statement expresses in full the ambiguity that pervades this "open space" as the "cross-pressure" from each perspective negates the other in a dialectic which leaves the subject in a state of logical paralysis. What is extremely important to note is that, from the disbelieving pole, it is on the question of Mason's sanity that this ambiguity hinges. This question is one that is pivotal to the text as a whole, being asked of Rayber, of Tarwater, and ultimately, of the reader as well. The faith by which it is answered gives the text its meaning.

Prior to kidnapping Rayber, Mason was institutionalized for four years in a mental hospital as a direct result of his prophesying. Before giving his sister up for lost and focusing his attention on her children, Mason was in the habit of visiting her every Wednesday to bring her around to repentance. One Wednesday his sister had "two men and a doctor" waiting for him with "the papers made out to commit him to the asylum if the doctor thought he was crazy" (369). After Mason "raged through her house like a blinded bull," the doctor declared him "not only crazy but dangerous" and "had taken him to the asylum in a strait jacket" (369). Mason spent four years there because it had "taken him four years to understand that the way for him to get out was to stop prophesying on the ward" (369). In "Confinement and Violence, Flannery and Foucault," William Monroe writes, "Foucault claims that prisons and asylums are required for the inculcation of a way of knowing, a communal mind-set, an episteme" (215). According to this view, Mason's commitment would amount to the containment of an aberrant "way of knowing" by the dominant episteme. Monroe's non-committal tone, however, makes it 
difficult to determine whether or not he believes this to be the case. In attributing this position to Foucault rather than claiming it as his own, Monroe is perhaps intuiting Mason's objective ambiguity, thus allowing for the contrary possibilities that Mason is the victim of arbitrary power or is genuinely insane. Yet, as a grown man, attempting to sustain his own "naïve" faith in disbelief, Rayber uses this episode and the doubt it casts on Mason's sanity, as a central justification.

Of course the doubt cast on Mason's sanity represents the doubt cast on the sanity of religious belief, a "way of knowing" that flies in the face of secular modernity's positivist Zeitgeist. This skepticism is not at all foreign to twentieth century thought, indebted as it is to Sigmund Freud. In a 1907 essay entitled "Obsessive Actions and Religious Practices" Freud characterizes neurosis as "individual religiosity" and religion as "a universal obsessional neurosis" (435). In "Civilization and Its Discontents" Freud rationalizes the mystical or “"oceanic" feeling experienced by a correspondent by speculating that "Pathology has made us acquainted with a great number of states in which the boundary lines between the ego and the external world become uncertain or in which they are actually drawn incorrectly" (724). Furthermore, in defining the scientific Weltanschauung, of which he is an admitted adherent, Freud allows "no knowledge derived from revelation, intuition or divination" but only the knowledge arrived at through "the intellectual working-over of carefully scrutinized observations" (784). The former types of non-knowledge can thus be "reckoned as illusions, the fulfillment of wishful impulses" (784). Freud thus manages to rationalize as pathological both the beliefs and rituals of religion, as well as the possibility of mystical revelation and prophecy. 
It is this scientific Weltanschauung and "way of knowing" endorsed by Freud that Rayber adopted as a grown man. After a car wreck claimed the lives of Rayber's parents and sister, the latter living just long enough to give birth to young Tarwater by the side of the road, Mason went into the city to live with Rayber, secretly entertaining the hopes of converting him and baptizing young Tarwater. Over the course of his stay, Mason was questioned and scrutinized by Rayber at length: "The schoolteacher had appeared to have a great interest in his [Mason] being a prophet, chosen by the Lord, and had asked numerous questions, the answers to which he had sometimes scratched down on a pad" (O'Connor TVBIA 341). Furthermore, "He questioned him at length about his early life, which old Tarwater had practically forgotten" (341). In other words, Rayber "had secretly been making a study of him" (331). The result of this study was an article published in a “"schoolteacher magazine" in which it was proclaimed of Mason that "'His fixation of being called by the Lord had its origin in insecurity. He needed the assurance of a call, and so he called himself" (341). Extending Foucault's argument to the human sciences themselves as "modes of confinement," Monroe writes, "Like the prophets of old in whose line he sees himself, [Old] Tarwater's nonconformity has been trapped and contained, not physically, but by a system of knowledge" (219-220). This seems to explain Mason's horror at having been reduced to a "piece of information" (O'Connor TVBIA 339) inside Rayber's head. A "system of knowledge" or "closed world structure" had circumscribed his reality within its own, turning Mason into an object of study. Were Mason's belief shaken by this, he too would have suffered "cross-pressure," but it was not. Rather, his horror was directed towards his nephew's betrayal. 
All of this represents an attempt by Rayber to sustain a "naïve" faith in disbelief. Through rationalizing his uncle's "fixation," he was attempting to escape the "crosspressure" he had experienced since his first trip to Powderhead as a child. The accusations which he directed towards Mason bear this out:

"You're too blind to see what you did to me. A child can't defend himself. Children are cursed with believing. You pushed me out of the real world and I stayed out of it until I didn't know which was which. You infected me with your idiot hopes, your foolish violence. I'm not always myself. I'm not. .." (377).

After trailing off, he further claimed, “'There's nothing wrong with me [... I I've straightened the tangle you made. Straightened it by pure will power. I've made myself straight" (377). An ironic use of the prophet's injunction to "Make straight the way of the Lord" (New American Bible, John 1:23), Rayber's claim to have made himself straight represents an instance of wishful thinking. Clearly, the initial cleavage of reality engendered by his uncle's indoctrination of him as a young boy continued to assail him with a "cross-pressure" which he vainly sought to deny.

As previously mentioned, the first sentence of the novel announces Mason's death. All of the above is, therefore, back story, told by means of flashback. The novel concerns the next generations for whom the "naïve" faith of their fathers is a dead thing. While Rayber does attempt to cling to a "naïve" faith in disbelief, evident through both his Freudian interpretation of his uncle's fixation and through the religious guise with which O’Connor dresses his humanistic creed, this ultimately fails him. In other words, despite his seeming conviction that "'you've got to be born again [. . .] by your own efforts, back 
to the real world where there's no savior but yourself'" (O'Connor TVBIA 379), he is still "cross-pressured". We read of moments when Rayber is overcome by a "horrifying love" (401) which he associates with his uncle. Initially triggered by his retarded son Bishop, whom he generally regards as a mistake, "as an x signifying the general hideousness of fate," this love is described as both "irrational and abnormal" and as "powerful enough to throw him to the ground in an act of idiot praise" (401). Rayber attempts to rationalize this love as fundamentally pathological, thus following from his judgment concerning his uncle:

The affliction was in the family. It lay hidden in the line of blood that touched them, flowing from some ancient source, some desert prophet or pole-sitter, until, its power unabated, it appeared in the old man and him and, he surmised, in the boy. Those it touched were condemned to fight it constantly or be ruled by it. The old man had been ruled by it. He, at the cost of a full life, staved it off. What the boy would do hung in the balance (402).

We see in this last sentence an allusion to the "open space" in which young Tarwater dwells throughout the novel. And while Rayber speaks of a "staving off" of the affliction to which his uncle succumbed, as though he were the latter's polar opposite on the spectrum of belief, it is obvious that he is still very much "cross-pressured" and that any such "staving off" represents an act of faith in the direction of disbelief. This sense of an act and the "cross-pressure" which necessitates it comes out more explicitly in the following:

[Rayber] knew that he was the stuff of which fanatics and madmen are made and that he had turned his destiny as if with his bare will. He kept 
himself upright on a very narrow line between madness and emptiness, and when the time came for him to lose his balance, he intended to lurch toward emptiness and fall on the side of his choice (402).

Thus from within the "open space" of the "immanent frame" the choice between belief and disbelief appears to Rayber to be a choice between "madness and emptiness". This follows from the fact that the "immanent frame" is an epistemological stance flowing from Enlightenment humanism and its watered down religious predecessors for whom religion came to be based on purely rational grounds. From such a religious outlook, anyone claiming communion with God or prophetic insight was labeled a "fanatic" or "enthusiast" and as fundamentally dangerous to the socio-economic order. It is easy to see Freud as a direct descendent of this position on religion, taking his rationalization a step further into the realm of pathology. On the other side, this same Enlightenment humanism, once fully entrenched, came to be regarded by many as reducing life to emptiness wherein a void of deeper meaning and feeling permeated human affairs. Caught between these two possibilities, between "madness and emptiness," Rayber finds himself in a predicament uniquely characteristic of a secular age, founded as it is on an "exclusive humanism". To go one way or another necessitates faithful action.

While young Tarwater is characterized as having "ideas of his own" (O'Connor TVBIA 332), a characteristic also attributed to Rayber and thus viewed pejoratively from the pole of Mason's "naïve" faith, so long as the latter was alive it was possible for him to combat such liberality of mind in his great-nephew. In other words, any doubt harbored by Tarwater could be authoritatively stamped out by Mason. From the very beginning of the text the reader gets an impression of how much depends, for Tarwater, 
on Mason's authoritative word. We have already seen that Tarwater's entire understanding of world history depended on the "naïve" faith of his great-uncle. Yet it goes much deeper than this. As Gary M. Ciuba notes, "Tarwater learned about his disastrous origins from the at least weekly retelling of the story by the old man who was [in O'Connor's words] 'Tarwater's great-uncle, or said he was'” (64 Ciuba's emphasis). Thus, for Tarwater, an orphan, everything is based on his great-uncle's word, even the credibility of that word. Thus, when O'Connor writes, "The old man, who said he was a prophet, had raised the boy to expect the Lord's call himself and to be prepared for the day he would hear it" (TVBIA 332 my emphasis), she is giving the reader an insight into the ambiguity of Mason's character and a foreshadowing of the crisis that Tarwater will have to face now that his great uncle is dead.

This ambiguity emerges even more fully for the reader when O'Connor describes Mason's occasional struggles with God, when he would retreat into the woods for days on end. She writes that "he would wander into the woods and leave Tarwater alone in the clearing, occasionally for days, while he thrashed out his peace with the Lord, and when he returned bedraggled and hungry, he would look the way the boy thought a prophet ought to look" (334). Though this description certainly conjures up images of the story of Jacob in the Old Testament who, through wrestling the whole night with God, is renamed "Israel," which means, literally, "to wrestle with God," the reader, at this point, is aware that back in the woods is where Mason stashed his still. The reader can't help wondering, therefore, if Mason's "retreats" aren’t in fact alcoholic binges. Tarwater's vision of his great-uncle upon the latter's return from these occasional retreats raises this question as well: "He would look as if he had been wrestling a wildcat, as if his head were still full of 
the visions he has seen in its eyes, wheels of light and strange beasts with giant wings of fire and four heads turned to the four points of the universe" (334). In light of the knowledge of the still, this description can be read either as the picture of a prophet returning from an encounter with God in the wilderness, or that of a self-deluded drunk, terminally warped by corn-whiskey and the bible, staggering home with a bad case of delirium tremens. Of course it is quite possible that the two are not as mutually exclusive as one would initially assume. The important point is that this too gives the reader insight into the ambiguity of Mason's character, an ambiguity with which Tarwater must reckon now that his great-uncle is not alive to "spin" it in his favor.

We see several instances of this "spinning” through which Mason resolves fundamental ambiguities in his own history. For example, the episode of his commitment is explained as his sister having "worked a perfidy on him" (368). Because Mason had characterized his sister as a "whore" who had "run away from Powderhead when she was eighteen years old" (366) Tarwater could conceive of her betraying Mason and thus any doubt as to his great-uncle's sanity could be assuaged or repressed. Similarly, the story of Rayber's conversion and subsequent de-conversion could be explained as resulting from the fact that "when the schoolteacher was seven years old, he had good sense but later it dried up" (355). Rayber's rejection of Mason's world view thereby loses any credibility. Those who oppose him are either traitors or dupes. Thus, while Tarwater may harbor “ideas of his own," his great-uncle's living presence had been able to counter those ideas and circumscribe Tarwater within the boundaries of a "naïve" faith.

With Mason's death those boundaries collapse and Tarwater is thrust out into the “open space” of a metaphysical no man's land. Prior to his death, Mason had been greatly 
concerned that he would receive a proper burial from his great-nephew. Consequently, after Mason dies at the breakfast table one morning, Tarwater finally says to him, "“Just hold your horses. I already told you I would do it right"” (336). What is especially important, however, is the following sentence: “The voice sounded like a stranger's voice, as if the death had changed him instead of his great-uncle" (336). Thus "the stranger," Tarwater's shadow-self, the composite being of all his doubt and confusion, emerges with the death of Mason, signifying the simultaneous death of the "naïve" faith Mason represented for him. At first this stranger only inhabits Tarwater's voice, but it soon takes on a life of its own inside his head, being described as "loud and disagreeable" (337). Tarwater is now divided against himself. Whereas he had "always followed his [great] uncle's customs up to this date" (337), he can now reject those customs in favor of others if he so chooses.

While Tarwater is digging his great-uncle's grave, the stranger is objectified, his face being described as "sharp and friendly and wise, shadowed under a stiff broad-brimmed panama hat that obscured the color of his eyes" (352 my emphasis). This objectification represents a self-image emerging in Tarwater's consciousness. The fact that this selfimage is emerging at the site of his great-uncle's grave illustrates a movement from a "naïve" to a "reflexive" state of being. O'Connor thus writes, "He began to feel that he was only just now meeting himself, as if as long as his [great] uncle had lived, he had been deprived of his own acquaintance" (352).

Referring to the stranger, Marshall Bruce Gentry writes, “The status of Tarwater's 'friend', the voice that urges him away from the role of prophet, has produced considerable controversy" (148). He further writes, "Some critics [...] label[ ] the friend 
as the Devil. Most critics assert that to some extent the friend expresses Tarwater's desires" (148). Situating The Violent Bear It Away in the context of "desert spirituality," Richard Gionne identifies the stranger as the objectification of "logismos," or a "satanic 'thought flow"” (152). He writes, "In ascetic-monastic usage, logismos most frequently occurs in the plural, logismoi, and is invariably allied to demons to mean evil or passionate thoughts" (152). This, however, remains ambiguous in that the demons are linked to thoughts rather than objective beings. This ambiguity between the devil and self-image is also present when the stranger tells Tarwater, “'It ain't Jesus or the devil. It's Jesus or you'" (O'Connor TVBIA 354). But whether the stranger is ultimately demonic, egocentric, or both, a particular form of reflexivity is here introduced into Tarwater's consciousness that is indicative of the disengaged stance that both Taylor and Heidegger identify with the metaphysics of the modern self. This disengaged stance is the stance assumed by all those inhabiting the "open space" of a secular age where the self can choose amongst world views from which it is fundamentally separate. Tarwater thus fully enters the world of doubt and confusion which Rayber had been thrown into as a boy.

The objectified stranger, representing all of Tarwater's previously latent doubts, thus begins to attack Mason and everything he represented to Tarwater as certain truth, first raising the question of his sanity, which, as we have seen, represents a central point of ambiguity in the text. Comparing Tarwater to Rayber, the stranger says:

“the truth is that you're just as smart, if you ain't actually smarter, than the schoolteacher. Because he had somebody — his daddy and his motherto tell him the old man was crazy, whereas you ain't had anybody and yet 
you've figured it out for yourself. Of course, it's taken you longer, but you've come to the right conclusion: you know he was a crazy man even even when he wasn't in the asylum, even those last years" (354).

Then linking Mason's insanity to his religious obsession, the stranger says, “'Or if he wasn't actually crazy, he was the same thing in a different way: he didn't have but one thing on his mind. He was a one notion man. Jesus. Jesus this and Jesus that" (354). Thus, one of the main currents of "cross pressure" coming from the pole of "naïve" unbelief assails Tarwater head on in the "open space" in which his great-uncle's death has left him.

The stranger also attacks Mason as a source of authority in an attempt to undermine the entire world view he presented to Tarwater as objective truth. As we have seen, Mason's authority was self-justifying, and now that he is dead it is easy to bring it into question. The stranger thus questions Tarwater:

\footnotetext{
"And how do you know the education he give you is true to the facts? Maybe he taught you a system of figures nobody else uses? How do you know that two added to two makes four? Four added to four makes eight? Maybe other people don't think so. How do you know if there was an Adam or if Jesus eased your situation any when He redeemed you? Or how do you know if He actually done it? Nothing but that old man's word and it ought to be obvious to you by now that he was crazy" (359).
}

Here the stranger is casting doubt on the world view of Mason's "naïve" faith which, as we have seen, is described on page one as having been imparted to young Tarwater. What is also noticeable is that a form of knowledge based on self-justifying authority is being 
undermined by one that appeals to first-hand experience and observation. This too represents a current of "cross pressure" coming from the pole of "naïve" unbelief, characteristic of the Freudian-scientific-positivist Weltanschauung. In fact the two currents, the one undermining Mason's sanity, and the other undermining his authority, are perhaps better understood as one. For, it is precisely his authoritative claim to knowledge that resists scientific observation that allows his sanity to be questioned by those for whom scientific knowledge is the only valid form. Hence, in the final sentence of the previous quote his "word" is associated with his being "crazy".

After failing to bury his great-uncle and getting drunk on corn whiskey Tarwater sets fire to the house in which he and Mason lived and leaves Powderhead for the city. This is a very symbolic gesture. In refusing to bury his great-uncle and erect a cross to mark the spot where the body lies in anticipation of the future resurrection, Tarwater is rejecting Mason as an absolute authority on reality. He then sets out on the highway and gets a ride from a travelling salesman. While driving into the city, Tarwater tells the salesman about his great uncle's supposed vocation as a prophet. Meeks, the salesman, says to Tarwater in reply, "'You ain't so sure about what all this great-uncle of yours told you? [...] You figure he might have got aholt to some misinformation"” (381). To this, Tarwater simply responds, "I'll find out"” and when asked how, he replies, "I mean to wait and see what happens"" (381). Later after he has arrived in the city and gone to stay with Rayber, his only blood relation, Tarwater says, "'I only come to find out a few things,"” and again, when asked how, he responds, "I'll wait and [. . .] see what happens"” (397). Tarwater is thus suspended in the no man's land, dead set on resolving its ambiguity. And unlike Rayber, he is not vainly attempting to cling to an impossible "naïve" faith. 
Much of the ambiguity in the central part of the text centers on the character of Bishop. Bishop is Rayber's only son, and thus Tarwater's cousin. He is a five year old idiot albino who bears a striking resemblance to Mason. The latter, while alive, had vowed that either he or Tarwater, whom he was raising to be a prophet as well, would see the child baptized, a vow at which Rayber had scoffed. This need to baptize, a "morbid impulse" (424) according to Rayber, clearly haunts Tarwater upon his arrival in the city. Standing face to face with Bishop, Tarwater "[s]uddenly $[\ldots]$ knew that the child recognized him, that the old man himself had primed him from on high that here was the forced servant of God come to see that he was born again" (389). A couple days later when Tarwater, Rayber and Bishop are walking through a large city park, they come upon a fountain into which Bishop bounds instantly. Tarwater "stood arrested in the middle of a step. His eyes were on the child in the pool but they burned as if he beheld some terrible compelling vision" (421). Furthermore, "He seemed to be drawn toward the child in the water but to be pulling back, exerting an almost equal pressure away from what attracted him" (421). A sense of being caught between the pull of two opposite poles is clearly evident in this description. As soon as Rayber understands what is happening he grabs Bishop out of the water, thus saving Tarwater from "committing some enormous indignity" (421). From this episode Rayber concludes that "The old man had transferred his fixation to the boy, had left him with the notion that he must baptize Bishop or suffer some terrible consequence" (421). For his part, Tarwater simply tells himself, staring at his reflection in the fountain, "I wasn't going to baptize him [... .] I'd drown him first" (432). The fact that he addresses these two possibilities, those of 
baptizing and drowning, to his own reflection, illustrates the reflexive "cross-pressure" of the "open space" in which he dwells.

What we see here is that the possibility of Mason's insanity has now become the possibility of Tarwater's insanity. In other words, it is possible now that Tarwater bears the "fixation" and "morbid impulse" that had once "ruled" Mason. Furthermore, it is a possibility of which Tarwater is well aware. This possibility, presenting itself to both reader and central protagonist, maintains the fundamental ambiguity of the text. We do know that one of the reasons Tarwater does not wish to baptize Bishop is because he feels that it is beneath him as a prophet. In other words, having been schooled on the Old Testament prophets, Tarwater feels that he should be called to something greater than "baptiz[ing] one idiot child" (389). This reasoning goes along with his general disdain for Jesus and the humble sacrifice He represents. If this were his only motivation, he would no longer be feeling cross-pressured. But this motivation against baptizing Bishop is mixed with another, namely, that the rite is meaningless and the vocation he has been raised for, a delusion. Thus, his shadow-self tells him, "you have to quit confusing a madness with a mission. You can't spend your life fooling yourself this way" (433). This reveals that Tarwater is still feeling the cross-pressure from both the pole of belief and disbelief, as is the reader. We also see the introduction of the baptism/drowning distinction, correlating to that of belief/disbelief, and which is central to the text's resolution and also focused on the character of Bishop and his overall significance to the text.

According to Rayber, his father, Bishop is a "mistake of nature" (403). Upon hearing Mason's vow to baptize the child, Rayber responded by saying, "'You could slosh water 
on him for the rest of his life and he'd still be an idiot. Five years old for all eternity, useless forever'” (351). Even Rayber's relationship to the child is, however, somewhat ambiguous. We have already seen that Bishop represents the source of the "horrifying love" to which Rayber is at times subject. As the object of this love, however, he also limits it. We read that, "It began with Bishop and then like an avalanche covered everything his reason hated" (401). Without having Bishop on which to focus this love whenever it surged up from his "afflicted" bloodline, Rayber believes that, "the whole world would become his idiot child" (442), a thought which horrifies him. When Rayber once attempted to drown Bishop, he couldn't go through with it because, while holding him under, "he had a moment of complete terror in which he envisioned his life without the child" (419). This "complete terror" did not stem from the fact that the "horrifying love" would abate, but that it would overwhelm him and turn him into his uncle. Thus Rayber is "cross-pressured" from two poles that seem to meet in Bishop, the latter being both the source of and limit to the "horrifying love" Rayber so abhors.

More important to the meaning of the text, however, is the ambiguity of Bishop's character in relation to Tarwater. Prior to the day on which he goes with Bishop and Rayber to the city park, Tarwater "demanded an unmistakable sign of the Lord" (431). At the park on the following day he observes Bishop in the fountain:

The child stood grinning in the pool, lifting his feet slowly up and down as if he liked the feel of wet seeping into his shoes. The sun, which had been tacking from cloud to cloud, emerged above the fountain. A blinding brightness fell on the lion's tangled marble head and gilded the stream of water rushing from his mouth. Then the light, falling more gently, rested 
like a hand on the child's white head. His face might have been a mirror where the sun had stopped to watch its reflection (432).

To this, Tarwater's shadow-self says, mockingly, “'Well, that's your sign [. . .] the sun coming out from under a cloud and falling on the head of a dimwit. Something that could happen fifty times a day without no one being the wiser"' (433). This, of course, is one way to interpret the event, and seemingly valid. There is nothing necessarily meaningful in the sun coming out and glaring rather distinctly upon the head of an albino. On the other hand, however, this could be a sign from on high calling Tarwater to his true vocation. The scene is rather reminiscent of the gospel passage in which John the Baptist baptizes his cousin, Jesus Christ, on whom the Spirit descends like a dove, a scene Tarwater would be familiar with. This reading resonates with the book's title and epigraph which contains an allusion to John the Baptist: "FFrom the days of John the Baptist until now, the kingdom of heaven suffereth violence, and the violent bear it away' Matthew 11:12" (329). Thus, for both Tarwater and the reader, the "cross pressure" from the poles of belief and disbelief also become centered on Bishop.

Of course, this demands entertaining the possibility that Bishop is a Christ-figure. There are many ways in which this seems plausible, but merely plausible. For one, Bishop's status as an idiot resonates with the traditional figure of the "holy fool". This figure is quite common in literature, one example being that of Prince Myshkin in Dostoevsky's The Idiot. Because of his status as an idiot, Bishop is described, by Mason, as incorruptible. When Mason and Tarwater first confront Bishop, the latter is described as "gnawing on a brown apple core" (349). This could certainly be read as signifying an imperviousness to the original sin of knowledge, a sin of which his father, Rayber, is 
deemed guilty by Mason. Bishop could thus be read as a being without sin. Thus, his baptism would be more for Tarwater's sake than for his own. This too could be seen as reflecting the baptism of Christ by John the Baptist. There is also the fact that in the fountain scene, the sun, a homonym of Son, is described as seeing its reflection in the child. Finally, there is his name: Bishop. While it is true that on the literal level it comes directly from his mother, Bernice Bishop, "the welfare woman" (333), in the Catholic Church to which O'Connor belonged a bishop is persona Christi. It is thus quite possible that, on the anagogical level, Bishop is persona Christi in the text.

Karl E. Martin, in his reading of the text, associates Mason rather than Tarwater with John the Baptist and the "prophetic kingdom" (163). Though he does associate Bishop with the "messianic kingdom" (164), he stops short of seeing in the latter a Christ-figure. He writes, “After associating Mason with the prophetic paradigm of the Old Testament carried into the New Testament in the person of John the Baptist, O'Connor employs Bishop as an emblem of the messianic kingdom inaugurated by Jesus" (163-64). He continues, "But aligning Bishop with the messianic kingdom is more problematic than aligning Mason with John the Baptist, for O’Connor has no intention of turning Bishop into a Christ figure or even a messianic figure" (164). Martin's argument, however, seems questionable. Referring to the episode of the sun shining down on Bishop in the fountain, he writes, "The point here is not to establish Bishop as a Christ-figure but rather to associate Bishop closely with the mysterious presence of God in the world and thus with the arrival of the messianic kingdom of heaven as defined by Jesus" (167). From this it is unclear what precisely Martin means by "Christ-figure". Clearly the term is not limited to denoting Jesus Himself. What does Martin imagine a "Christ-figure" to be 
other than the "mysterious presence of God in the world" heralding the advent of the "messianic kingdom of heaven as defined by Jesus"? One could perhaps add to this description the suffering of an unjust death, a criterion which Bishop's character also fulfills. Bishop is clearly either a Christ-figure in all of the aforementioned ways, or he is quite simply an idiot.

Of course, it is only for the reader that the possibility of Bishop as a Christ-figure emerges. For Tarwater, Bishop is an idiot. The question Tarwater faces is whether Bishop is an idiot who "cries out for baptism" (O'Connor TVBIA 350) or an idiot who would be just as good drowned. When Rayber takes the two boys to a lakeside lodge outside the city, he is hoping to elicit a response from Tarwater so that the latter can, once and for all, confront his "morbid impulse" to baptize. Shortly after they arrive there, Tarwater decides that it is time to act, that since nothing has happened, he will "make it happen". He thus says to the desk lady, "“you can't just say NO [. . .] You got to do NO. You got to show you mean it by doing it. You got to show you're not going to do one thing by doing another. You got to make an end of it. One way or another"” (428). This, once again, shows the "cross-pressure" assailing Tarwater and the need to ultimately make an act of faith "One way or another" in order to move forward.

After dinner one night, Tarwater takes Bishop out in a boat on the lake while Rayber rests in his room. The reader does not actually see the drowning, but hears it from the perspective of Rayber standing at his window, staring out into the darkness. We read, "The quiet was broken by an unmistakable bellow" (455). Furthermore, "The bellow rose and fell, then it blared out one last time, rising out of its own momentum as if it were escaping finally after centuries of waiting, into silence" (456). Rayber "remained 
standing woodenly at the window. He knew what had happened. What had happened was as plain to him as if he had been in the water with the boy and the two of them together had taken the child and held him under until he ceased to struggle" (456). It is here that we see, not so much an act of faith, but the consequence of the many acts of faith Rayber has been making all along through stifling and repressing the "horrifying love" welling up inside of him. We come to see that each such act has represented a faithful choice in favor of unbelief over belief, and that finally these choices are coming to fruition. We thus read, "He stood waiting for the raging pain, the intolerable hurt that was his due, to begin, so that he could ignore it, but he continued to feel nothing. He stood light-headed at the window and it was not until he realized there would be no pain that he collapsed" (456).

John F. Desmond reads this "final view of Rayber" as “open-ended" (53). He claims that it "is not marked by the closure of neat allegory," but rather, "preserves the limits of fiction and avoids any dogmatic conclusion" (53). While Desmond is quite correct in identifying a fundamental ambiguity in this "final view of Rayber," the ambiguity he identifies is the wrong one. The question he asks is whether Rayber has committed “spiritual suicide," or whether, in the wake of Bishop's death, Rayber will finally “confront the mystery of his own heart" (53-54). Desmond is thus presupposing a metaphysical ground that O'Connor has not provided. In other words, he is assuming that the Christian world view correlates to reality. The ambiguity he identifies has to do with Rayber's future within this unambiguously defined reality. The real question does not concern Rayber's future within a definite Christian metaphysics, but rather, his decisions within the ambiguous reality of the text. Because the precise nature of reality is and 
remains ambiguous throughout the text, the question is whether or not Rayber has rightly responded to that reality through the many acts of ignoring the "horrifying love" which he deemed a mania. All that is unambiguously clear is that Rayber has placed his faith in unbelief and has thereby escaped the metaphysical disorientation of "cross-pressure".

The ambiguity is, however, not yet resolved for Tarwater. We get a foreshadowing of this through Rayber: "He knew with an instinct as sure as the dull mechanical beat of his heart that he [Tarwater] had baptized the child even as he drowned him" (O'Connor TVBIA 456). When a disheveled Tarwater is then picked up by a truck driver on the highway, this is affirmed. The truck driver asks Tarwater why his pants are wet, and the latter admits "II drowned a boy"” (458). This admission is followed by another. Tarwater says, "“I baptized him [. . . I I didn't mean to [. . .] The words just come out of themselves but it don't mean nothing. You can’t be born again"” (458). He further says, “'I only meant to drown him"” (458). Thus, despite his firm intention to choose one way over another, he is still caught in the "cross-pressure". It is uncertain, both to Tarwater and the reader, whether his need to baptize stems from his vocation as a prophet or from a "morbid impulse" passed onto him from Mason. What is certain, at this point, is that he cannot escape the pressure from either pole. Thus, while telling the truck driver that he is going back to Powderhead, Tarwater says, "'I shouldn’t never have left it except I had to prove I wasn't no prophet and I've proved it [. . . I I proved it by drowning him. Even if I did baptize him that was only an accident"' (458). Tarwater thus appears just as conflicted as he had been staring at Bishop in the fountain that day in the park.

This sense of being conflicted and riven inwardly becomes even more apparent when Tarwater is later walking along the highway: 
Beyond the glare, he was aware of another figure, a gaunt stranger, the ghost who had been born in the wreck and who had fancied himself destined at that moment to the torture of prophecy. It was apparent to the boy that this person who paid him no attention, was mad (465).

There is sense in which Tarwater sees himself as possessed, or haunted, by a ghost of madness bent on the "torture of prophecy". That he can see himself in such a way and judge himself mad again illustrates the reflexive stance of disengaged reason. There are thus two of him walking along the highway "toward a violent encounter with his fate" (456).

Tarwater is then picked up by an "old-looking young man" (469) who drugs him. Though the reader is not witness to an actual sexual assault, such an assault is implicit in the fact that when Tarwater regains consciousness he is naked save for his shoes. There is reason to suspect that the predator who has left him in the woods in such a state is demonic. He is, for instance, described as having eyes the color of lavender (469). His description also bears similarity to that of the stranger. This raises the possibility that Tarwater's shadow self has, in fact, had an objective source in the realm of the supernatural all along. None of this is explicitly stated, however, and remains mysterious and uncertain. When Tarwater reaches an outlook overlooking Powderhead, the stranger says to him, "Go down and take it [...] It's ours. We've won it. Ever since you first begun to dig the grave, I've stood by you, never left your side, and now we can take it over together, just you and me" (475). The presence of the stranger is then described as being "pervasive as an odor" and as a "violet shadow hanging around his shoulders" (475). There is, again, a sense of the demonic in this description and a link with the 
perpetrator of the implied rape. All of this is rendered more ambiguous, however, due to the fact that Tarwater has not only recently been drugged and likely raped but he has not been able to eat anything for a long time despite being ravenously hungry. Anything he experiences in this disturbed mental state is thus undermined a priori.

After setting fire to the foliage around him and building a wall of flame between himself and the stranger Tarwater descends into the clearing. Just prior to this, we read, "[t]he broad road began to narrow" (474), an allusion not only to the "narrow gate" spoken of by Christ (Matt. 7:13), but also to the incendiary death of this, his divided self, a death which ultimately symbolizes a narrowing of the broad spectrum of "open space" into an imminent act of faith. In the clearing, after speaking with his neighbor, Buford Munson, Tarwater receives his vision. Looking out across the field,

It seemed to him no longer empty but peopled with a multitude.

Everywhere he saw dim figures seated on the slope and as he gazed he saw that from a single basket the throng was being fed. His eyes searched the crowd for a long time as if he could not find the one he was looking for. Then he saw him. The old man was lowering himself to the ground. When he was down and his bulk had settled, he leaned forward, his face turned toward the basket, impatiently following its progress toward him. The boy too leaned forward, aware at last of the object of his hunger, aware that it was the same as the old man's and nothing on earth would fill him. His hunger was so great that he could have eaten all the loaves and fishes after they were multiplied (O'Connor TVBIA 477-78 my 
emphasis).

Tarwater is thus identifying with the hunger of his great-uncle. Earlier in the novel, this hunger is precisely what Tarwater feared and identified as "his great-uncle's madness" (342-43). Then, Tarwater, "was secretly afraid that it might be passed down, might be hidden in the blood and might strike some day in him and then he would be torn by hunger like the old man, the bottom split out of his stomach so that nothing would heal or fill it but the bread of life" (343). In this concluding scene, his estimation of this hunger has changed as he gives himself over to it:

He felt his hunger no longer as a pain but as a tide. He felt it rising in himself through time and darkness, rising through the centuries, and he knew that it rose in a line of men whose lives were chosen to sustain it, who would wander in the world, strangers from that violent country where the silence is never broken except to shout the truth. He felt it building from the blood of Abel to his own rising and engulfing him (478).

This description of an otherworldly hunger being carried by an ancient blood line obviously resonates with the "afflicted" blood line Rayber sees as infecting himself, and as stemming from "some ancient source, some desert prophet or pole-sitter". This hunger is thus identical to the "madness" that Rayber opposes to "emptiness". After having a further vision of a "red-gold tree of fire" which is ambiguously mixed with the fire he had set, himself, in the trees, Tarwater hears the prophetic injunction, "GO WARN THE CHILDREN OF GOD OF THE TERRIBLE SPEED OF MERCY" (478). This hearing, however, is described as silent, "as seeds opening one at a time in his blood" (478). After 
making his way back to the highway, he sets out "toward the dark city, where the children of God lay sleeping" (479).

There is a definite sense, in this final scene, that Tarwater has overcome the "crosspressure" that has been assailing him, that he has finally chosen one way over another, that he has put his faith in belief and assumed the vocation of a prophet, no longer questioning his own and his uncle's sanity. For the reader, however, the ambiguity engendered by the "cross-pressure" of world views remains. Based solely on the evidence the novel presents, Tarwater's vision can be read as a genuine divine revelation or as a psychotic episode precipitated by any combination of intoxication, post-traumatic stress, and a possible hereditary form of madness. This ambiguity at the level of content coupled with the reader's own position within the "immanent frame" of a secular age leaves him/her on very shaky ground. The reader can picture Tarwater arriving in the city and taking his post on any street corner, and from there haranguing the passing citizens with fire and brimstone prophecies of approaching doom. The question the reader faces is whether this is the picture of a prophet or that of a madman?

That the terminus of the novel itself leaves the reader in such an ambiguous "open space" situates the novel within the genre of the fantastic. According to Tzvetan Todorov, a text is fantastic when it obliges the reader to "hesitate between a natural and supernatural explanation of the events described" (33). Furthermore, he writes, "this hesitation may also be experienced by a character" (33). In the case of The Violent Bear It Away, while neither Rayber nor Tarwater are left hesitating at the text's terminus, they both embody degrees of such hesitation throughout. Their hesitation comprises the dramatic action of the text. While much of their hesitation is between the ideational 
content of contradictory "world views," which is not fantastic in itself, there are clear instances where the possibility of supernatural agency arises and they find themselves caught between opposing interpretations. For instance, Tarwater's “terrible compelling vision" of Bishop in the park fountain the day after he "demanded an unmistakable sign of the Lord" raises the distinct possibility of supernatural agency. And yet his shadow self interprets the occurrence as a mundane everyday phenomena. There is also the possibility of divine inspiration in the "horrifying love" which threatens to throw Rayber to the ground "in an act of idiot praise". Yet he interprets the phenomenon as fundamentally pathological. Though it is true that Rayber is quicker to "explain away" such phenomena than Tarwater, the moment of hesitation, however brief, is unquestionably there.

Thus, what the characters experience at the level of content is experienced by the reader at the terminus of the novel. The reader must determine the meaning of the events described just as the characters had to assign meaning to events they experienced. Todorov remarks, “The fantastic [...] lasts only as long as a certain hesitation: a hesitation common to reader and character, who must decide whether or not what they perceive derives from 'reality' as it exists in the common opinion" (41). He further writes, “At the story's end, the reader makes a decision [...] he opts for one solution or the other and thereby emerges from the fantastic" (41). Were O'Connor to offer such a solution herself, the text would no longer be fantastic. A completely rational explanation of the apparently supernatural would lead the text into the territory of the "fantasticuncanny," whereas an unambiguous affirmation of a supernatural presence would lead the text into the territory of the "uncanny-marvelous" (44). Though it is quite possible for 
the reader to interpret Tarwater's vision as the uncanny phenomena of madness, an opinion which would follow from the "common opinion" of reality which grounds the secular "immanent frame," or conversely, to see his vision as beatific, and thus stray from that "common opinion," what is important to note is that the text leaves it essentially ambiguous.

Concurring with O'Connor's own statements, many critics have situated her work within the genre of the grotesque. A look at some of the definitions they give, as well as O'Connor's own definition of grotesque literature, reveals that within the context of a secular age the grotesque, so defined, and the fantastic must necessarily overlap. Gilbert H. Muller describes the grotesque as employed by O'Connor as, "a method of investigating certain metaphysical problems through fictive constructions" (5). Christina Bieber Lake refers to grotesque fiction as O'Connor employs it as "that place best able to celebrate created humanity in all its mystery" (34). Both of these definitions resonate with the definition offered by O'Connor in an essay entitled "Some Aspects of the Grotesque in Southern Fiction”. In the essay O’Connor claims that, "All novelists are fundamentally seekers and describers of the real, but the realism of each novelist will depend on his view of the ultimate reaches of reality" (815). She characterizes "grotesque" fiction as tending "toward mystery" (815), as "always [...] pushing its own limits outward toward the limits of mystery" (816). Thus, "grotesque realism" is chiefly concerned with discerning and depicting a mystery at the heart of reality. O'Connor thereby attributes to the writer of grotesque fiction a unique "prophetic vision" (817). She writes, "In the novelist's case, prophecy is a matter of seeing near things with their extensions of meaning and thus of seeing far things close up. The prophet is a realist of 
distances, and it is this kind of realism that you find in the best modern instances of the grotesque" (817). Of all her work, this bears particular meaning for The Violent Bear It Away, a book specifically dealing with the question of "prophetic vision," and it is here that we see the fantastic and the grotesque seamlessly coalesce. For, just as the characters in the novel inhabit a secular age grounded in the "immanent frame" of an "exclusive humanism," a frame which casts a dubious light on such anomalies as prophecy and divine mystery, so too does the reader, and just as the former must respond by an act of faith to any such anomalies, so too must the latter. Thus are characters and readers alike left hesitating before the possibility of mystery, called upon for a faithful decision. 
Out of Nihilism?

In a letter to an anonymous correspondent dated August 28, 1955, O’Connor writes, "if you live today, you breath in nihilism" ( $H O B$ 97). At first glance, this seems like a fairly straightforward statement, one which does not require a second glance. And yet, as Shane Weller masterfully elucidates in Modernism and Nihilism, the concept of nihilism is an ambiguous and slippery thing. Not only does it worm its way into a variety of discursive fields, but within a single field it often takes on different and contradictory meanings. It is thus fitting, as Weller makes clear, that Nietzsche refers to nihilism as the "uncanniest of all guests"” (13). For that which is uncanny is both familiar and unfamiliar, and therefore, entails a logical contradiction. According to Weller, since the inception of modernity, the "charge of nihilism" has been leveled at such disparate things as “atheism, Christianity, Judaism, rationality, metaphysics, ontology, transcendental idealism, logocentrism, deconstruction, technology, democracy, Nazism, fascism, socialism, bolshevism, humanism, and anti-humanism" (9-10). And where it has not been viewed as a pejorative label, nihilism has been championed as that which will "clear the ground for a new cultural beginning" (9). Nietzsche, alone, associates nihilism both with the initial positing of Platonic and Judeo-Christian transcendental values as well as with the decay of those values (32-33). He associates nihilism with the Schopenhauerian pessimism that seeks to deny the will in the face of a meaningless existence (35-36). He also associates nihilism with the overcoming of nihilism, paradoxically stating that only 
he, "the perfect nihilist," has " "lived through the whole of nihilism, to the end, leaving it behind, outside himself" (34). Thus for Nietzsche, "the perfect nihilist"” has in fact overcome nihilism. This positive Nietzschean overcoming must then be contrasted with the pejorative Heideggerian overcoming wherein one merely " "believes to have goals again," having "“methodically disregard[ed] human goalessness"” (54). This overcoming amounts to a denial, and thus represents, for Heidegger, "'the greatest nihilism”" (54).

It is thus far from clear what nihilism means precisely. It is even questionable whether it is ultimately positive or negative in nature. It is fitting, therefore, that O'Connor characterizes it as an atmospheric phenomenon, nebulous, yet so all-encompassing. Of all her work, it is Wise Blood that most directly addresses this uncanny atmosphere of nihilism. It is, therefore, in many ways, a harder book to make sense of than The Violent Bear It Away. Jordan Cofer alludes to this fact when he writes, "Most of the early readers of Wise Blood believed the novel to suggest the opposite of what O'Connor actually anticipated" (163). The novel's central protagonist, Hazel Motes, negotiating the "open space" of a secular age in post WWII America, overcomes the "cross-pressure" of nihilism through an act of faith in nihilism, thus becoming the "perfect nihilist," but in a manner which departs radically from Nietzsche's nihilistic vision. Thus Motes brings the uncanniness of nihilism full circle. Through changing the narrative point of view in the final chapter of the text to that of Hazel's landlady observing him from the outside, O'Connor places the reader in this uncanny atmosphere of nihilism, leaving the latter to determine the meaning of Motes's act and fate.

There are two major forms of nihilism evident in Wise Blood from which other more specific forms emerge. One of these major forms of nihilism is characterized by an 
indifference to truth and represents an implicit form of nihilism, while the other is characterized by a commitment to truth and represents an explicit form of nihilism. One helpful way to understand the difference is to look at the analogue that is found in Nietzsche's famous parable of the madman. In book three of The Gay Science Nietzsche writes, "Have you not heard of that madman who lit a lantern in the bright morning hours, ran to the market place, and cried incessantly: 'I seek God! I seek God!'” (181). After being laughed at by the people in the market "who did not believe in God," the madman concludes, "God is dead. God remains dead. And we have killed him"” (181). As Giles Fraser points out in Redeeming Nietzsche, "Here two fundamentally different forms of 'atheism' are being contrasted" (44). What is important to note is that the madman who is proclaiming God's death is also the only one seeking God. Though, in Wise Blood "God" is substituted for "Truth," it is here that we find an analogue in Hazel Motes. In other words, in Wise Blood, to rework Fraser, "two fundamentally different forms of [nihilism] are being contrasted": the nihilism of indifference which manifests in a contentment to dwell in relative notions of truth and which is embodied in the marketplace of Taulkinham, and the nihilism of commitment which seeks an absolute form of truth in "no truth" and which is embodied in Hazel Motes. Both imply what O'Connor calls a "dark night of the soul" (HB 100), though only the latter is fully conscious of the darkness.

The nihilism of indifference pervades the streets of Taulkinham. On his second night in town Hazel Motes finds himself wandering around the shopping district. He stops in front of a department store where "a lean-faced man had a card table set up [...] and was demonstrating a potato peeler" (O'Connor WB 19). The man's table of merchandise is 
described as an "altar" (19), making him the priest. In this way, the religion of the people is revealed as materialist consumerism, and the market as their place of worship. What makes this nihilism is clear in a passage that directly precedes this scene:

The black sky was underpinned with long silver streaks that looked like scaffolding and depth on depth behind it were thousands of stars that all seemed to be moving very slowly as if they were about some vast construction work that involved the whole order of the universe and would take all time to complete. No one was paying any attention to the sky (19).

The importance of this passage has been overlooked by some critics. Marshall Gentry writes, "The descriptions of stars and sky make the narrator's larger frame of reference ridiculous in relation to the lives of the characters" (122). He further writes that "The fancifulness of these passages suggests that the narrator is imposing a set of standards on the novel's content that is at once oppressive and misleading" (122). While Gentry's comments are revealing to the extent of discerning a gross discrepancy between the narrator's objective description and the subjective experience of the characters, it is clear that he misses the importance of this passage to the creation of an atmosphere of nihilism. In this description of the night sky, two of the values which Nietzsche views as having been lost with the advent of nineteenth century nihilism are seemingly present, namely unity and teleological purpose (Weller 30). That the universe is said to possess an "order" and that this "order" is said to be about some "vast construction work" that would "take all time to complete" plainly implies such values. Of course, Nietzsche would say that the very positing of such values by the Platonic and Judeo-Christian tradition is itself nihilistic, a possibility that is left open by the narrator's use of such qualifications as 
"seemed" and "as if". Such a reading would then account for the "oppressive" and "misleading" standards Gentry criticizes, making the narrator the principal nihilist. While it is, rather, with the nihilism of the masses that O'Connor is chiefly concerned, this possibility of a nihilistic narrator lends an uncanny dimension to the overall atmosphere of nihilism she is creating. For, if the narrator is nihilistic, the nihilism of the masses represents an overcoming of nihilism, and thus a movement towards reality. On the other hand, if the values to which the narrator eludes are objective facts, the nihilism of the masses represents a denial of reality. Thus, while the phrase, "No one was paying any attention to the sky," is unambiguously meant to evoke a loss of transcendent value and the atmosphere of nihilism that follows, it is left ambiguous as to whether there is, or ever was, something in the sky to be seen. This ambiguity represents a foreshadowing of the ambiguity which both Hazel Motes and the reader will face.

Though facing a loss of transcendent value, there is no intimation in this scene that the shoppers are in the throes of an existential crisis, that they are suffering from the pessimism which Nietzsche associates with Schopenhauer and views as a necessary "preliminary form of nihilism" (Will To Power 11). What O'Connor is describing in this scene is the form nihilism takes when the hole left by the loss of transcendent value, whether real or imagined, is covered up by the endless cycles of desire and consumption on which the capitalist system is sustained. It is the Heideggerian false overcoming, and therefore, “"the greatest nihilism"'. For though one may “"believe to have goals again,"” those goals are driven by advertisement campaigns which promise fulfillment but which leave one endlessly chasing after nothing. The novel as a whole is proliferated with images of such commodities, whether in the form of fast food, movies, automobiles or 
pop religion. Here, the nihilism of indifference manifests itself as consumerism elevated to the level of life's meaning. Though Hazel Motes is basically committed to seeking the Truth, he is nonetheless affected by this nihilism, it being in the very air he breaths. This is evident when he tells Sabbath Lily Hawks, "'Nobody with a good car needs to be justified"” (O’Connor WB 64). Here, Motes offers consumerism as a justification for existence, and thus, as a valid reason to live. In fact, Hazel buys a car as a place to live, telling Slade the used car salesman, "I ain't got any place to be"” (41), a line that is paradoxically reminiscent of Christ's statement that " "the Son of Man has nowhere to rest his head" (Matt 8:20). Brian Ragen views Hazel's Essex as a principle of freedom. He sees this as following from the American tradition which makes a virtue of mobility. He thus writes, "The automobile becomes the embodiment of the idea of complete freedom, freedom from the past and from responsibilities, freedom even from the taint of Original Sin and the need for a savior" (108). While the deracination Ragen is describing does characterize America and Motes to a degree, what should be emphasized rather than freedom is the car as a principle of existential justification that stands between Motes and the uncanny homelessness of nihilism.

Nihilistic indifference is also evident in several of the so-called "religious" figures in the text, all of whom are essentially frauds. There is, for instance, Asa Hawks, the exevangelist turned preacher-beggar who feigns blindness and hands out religious tracts with his homely daughter Sabbath Lilly. A wolf in sheep's clothing, Hawks is in reality an abusive drunkard who refers to Hazel as a "“Goddam Jesus-hog"” (O'Connor WB 62). There is also Hoover Shoats, aka Onnie Jay Holy, a man whose very name echoes the gospel warning of casting pearls before swine (Matt 7:6). To Shoats, the gospel is purely 
a commodity. He tells Hazel, "II was on the radio for three years with a program that give real religious experiences to the whole family. Didn't you ever listen to it—called, Soulease, a quarter hour of Mood, Melody, and Mentality? I'm a real preacher, friend" (O’Connor $W B$ 85). He also warns Motes that “'If you want to get anywhere in religion, you got to keep it sweet"' (89). Religion, to Shoats, is the business of selling comforting illusions to the public, thus turning "religious experience" into a commodity for mass consumption. Even his bastardization of the name of Hazel's Church reveals his hollow ploy. Where Hazel's church is simply called the "Church Without Christ," Shoats turns it into the "Holy Church of Christ Without Christ" (89). The former is founded on a simple negation, whereas the latter is founded on an empty affirmation. Thus Hazel's Church actually stands for something, though negatively, whereas Shoats's stands for nothing at all. Finally, there is the "Prophet" whom Shoats hires to outdo Hazel preaching on the street. This "Prophet", who actually believes in Jesus, is willing to get up on the hood of a car and preach against Him in order to make a buck. In all of the above cases, a gross indifference to integrity and truth is plainly evident.

In contrast to this nihilistic indifference of the marketplace is the nihilism of Hazel Motes, a nihilism that, uncannily, is both more and less nihilistic: more nihilistic because it unabashedly preaches that there is "no truth," but less nihilistic because the lack of truth of which it preaches is the only apparent truth. Thus, in one of his many streetcorner sermons, Motes proclaims, "'I preach that there are all kinds of truths, your truth and somebody else's, but behind all of them, there's only one truth and that is that there is no truth $[\ldots]$ No truth behind all truths is what I and this church preach"' (93). Motes' brand of nihilism thus makes explicit what is implied in the indifference of the crowd. 
And yet, his "conver[sion] to nothing" (12) preceded his move to Taulkinham. It took place during WWII when, after having joined the army with a determination to keep his soul free from corruption, he was one night invited by some of his fellow soldiers to go to a brothel. In response to their enticing invitation Motes told them that "he was from Eastrod Tennessee, and that he was not going to have his soul damned by the government or any foreign place" (12). In reply to his staunch moralizing, his fellow soldiers told him "he didn't have any soul and left for their brothel" (12). Hazel "took a long time to believe them because he wanted to believe them. All he wanted was to believe them and get rid of it once and for all, and he saw the opportunity here to get rid of it without corruption, to be converted to nothing instead of to evil' (12 my emphasis). This “conver[sion] to nothing" thus represents a repudiation of the absolute values of good and evil and their human seat, the soul.

Of course, this nihilism of amorality is central to Nietzsche's uncanny discourse on nihilism. In The Will to Power, for instance, Nietzsche writes that, through nihilism, it is "the moral god that has been overcome" (36). In other words, nihilism, as a process through which, "the highest values devaluate themselves" (9), is a process through which the values of good and evil become superfluous. This is certainly how O'Connor understands Nietzsche's proclamation on the death of God. In one of her letters, dated July 22, 1955, she writes:

it is easy to see that the moral sense has been bred out of certain sections of the population, like the wings have been bred off certain chickens to produce more white meat on them. This is a generation of wingless chickens, which I suppose is what Nietzsche meant when he said God was 
dead (HOB 90).

Of course, for Nietzsche, the "moral sense" of which O'Connor writes is itself nihilistic in that it reifies what he views as illusory values which negate the fundamental amorality of life. While one can in no way attribute such a position to O'Connor, and while Hazel Motes was indeed "bred" with "moral sense" intact, the Christian moral world view from which he converts to "nothing" can itself be characterized as nihilistic in the sense of positing empty values. The question Motes faces, and the reader in turn, is whether these values are empty because they are illusory as Nietzsche would have it, or because they have lost their mooring in the presence of God which alone can give them justification.

O'Connor's statement that "if you live today you breathe in nihilism," is followed by, "In or out of the Church it's the gas you breathe" (HOB 97). She, therefore, does not oppose contemporary currents of nihilism to a Church which ultimately stands aloof of them. Rather, as Ralph Wood duly notes, she is sympathetic to all those who would protest "the massive vacancy of soul that, largely unrecognized, characterizes modern religious life in the West" (180). Hazel Motes's grandfather is one such example of a religious "vacancy of soul". When Hazel was a child, his grandfather had been a "circuit preacher" who "[e]very fourth Saturday $[\ldots]$ had driven into Eastrod as if he were just in time to save them all from Hell" (O'Connor WB 9-10). From atop the nose of his "Ford automobile" (10) he would point at his grandson and harangue the crowd: "Did they know that even for that boy there, for that mean sinful unthinking boy standing there with his dirty hands clenching and unclenching at his sides, Jesus would die ten million deaths before He would let him lose his soul?" (11). While Henry Edmondson views the grandfather and the "moral and religious formation" he gave to Hazel as representative of 
the "Judeo-Christian heritage" (37), thus making Hazel the big bad nihilist who rejects this heritage, Richard Giannone offers a more insightful reading. The latter writes, “Transferred into his grandson's mind, Jesus, the slaughtered victim, becomes the pursuer of souls that he died to save; and the young Motes stands as living prey of this bleeding, skulking Jesus" (50-51). He further writes, "The old man succeeded in searing his ambush theology into Motes's mind, where Jesus takes on the force of the assailant, the liar, the enemy — in short, the demonic" (51). While this reading is a bit extreme, it illustrates a fundamental corruption in the religious world view with which Motes was inculcated. It also explains his particular dislike for the figure of Jesus. Where it falls short, however, is in not identifying the moralism into which this world view eventually degenerates.

Much like young Tarwater, the young Hazel Motes entertained a general dislike for the figure of Jesus. What is interesting, however, is the method by which he hoped to avoid Him:

There was already a deep black wordless conviction in him that the way to avoid Jesus was to avoid sin. He knew by the time he was twelve years old that he was going to be a preacher. Later he saw Jesus move from tree to tree in the back of his mind, a wild ragged figure motioning him to turn around and come off into the dark where he was not sure of his footing, where he might be walking on the water and not know it and then suddenly know it and drown. Where he wanted to stay was in Eastrod with his two eyes open, and his hands always handling the familiar thing, his feet on the known track (O’Connor $W B$ 11). 
Hazel thus believed that through preaching the gospel in Jesus' name, much like his grandfather, he would be able to avoid sin and, consequently, avoid Jesus. Hazel's grandfather, we read, "had a particular disrespect for him [Hazel] because his own face was repeated almost exactly in the child's and seemed to mock him" (11). Hazel's grandfather was thus aware of his own hypocrisy which he saw mirrored in his grandson. All of this gives specific meaning to an episode at the close of the first chapter when, after Hazel wakes up from a bad dream in his train berth and frantically sticks his head out into the aisle calling Jesus' name, the porter, standing in the aisle, replies, "“Jesus been a long time gone"' (14). What the porter's words signify is the fact that Jesus' name has become empty, devoid of any real presence or meaning, connoting what Charles Taylor refers to as "dry as dust moralism" (399) and the sanctimonious self-regard that ever is its malignant shadow. Thus when, two days prior to this, Hazel returned to his family home in Eastrod, he found that "the house was as dark as the night and open to it and though he saw that the fence around it had partly fallen and that weeds were growing through the porch floor, he didn't realize all at once that it was only a shell, that there was nothing here but the skeleton of a house" (O'Connor WB 13). As in The Violent Bear It Away, O'Connor is using the family home as a symbol of the family faith which, in this case, amounts to a decaying husk to which Motes cannot return to find shelter and meaning in the wake of the war. Both the house being described as "dark as the night" and the episode in the train berth which takes place in the darkness of night clearly imply a loss of divine presence, whether real or imagined, a loss that is characteristic of both the mystical dark night of the soul and humanist disenchantment. 
Thus, as a grown man repudiating good and evil as absolute values, Motes must ask himself the same question Nietzsche poses in The Will to Power: "Does it make sense to conceive of a god 'beyond good and evil'?" (36). While for Nietzsche this would entail an amoral god, for Motes the question is simply whether good and evil are based in anything greater, whether the "ragged figure" of his childhood is real or just a phantom, whether the darkness into which He leads is the darkness of God or the darkness of pitiable delusion. We often see Hazel grappling with this question in terms of sin. For instance, one day he stops on the highway to read a sign that says, "WOE TO THE BLASPHEMER AND WHOREMONGER! WILL HELL SWALLOW YOU UP?” (O'Connor $W B$ 42). When a truck driver whose route Hazel is blocking gets out of his truck and approaches Hazel's window, the latter says to him, “"There's no person a whoremonger, who wasn't something worse first [...] That's not the sin, nor blasphemy. The sin came before them"' (43). After saying this, Hazel nonetheless says to the truck driver, "Jesus is a trick on niggers"” (43). Here we see both an explanation of so-called sinful acts as being rooted in an unseen mystery and, conversely, as being purely illusions. We see this again in Hazel's first polemic with Asa Hawks. When Hawks accuses Motes of "“[f]ornication and blasphemy," the latter exclaims, "“If I was in sin I was in it before I ever committed any," but then follows this up by stating, "“I don't believe in sin," and finally, "Nothing matters but that Jesus don't exist"” (29). In both cases, though unaware, Motes is clearly referring to the possibility of original sin, that primordial act and condition which first rent and keeps man from the immanent presence of God. 
Essentially, through these deliberations on sin, Motes is seeking the ground of reality. That is, through the question of morality, Motes is attempting to discern for himself the metaphysical structure of reality beyond any abstract "world view". The two possibilities with which he is faced are: since there is nothing beyond that which his senses reveal, morality is ultimately unjustified, or, conversely, morality is grounded in something, which, given its indeterminate ontological status, is better qualified as no-thing. Thus we see the possibility of two very different "nothings" emerge: the "nothing" of morally relative humanism and the "nothing" of God, of which the values of good and evil are but a visible manifestation. This latter "nothing" is addressed in much Christian apophatic theology. Pseudo-Dionysius, author of "The Mystical Theology" writes of "the One who is beyond all things" (136) and dwells in darkness. To be "beyond all things" is to be nothing. Henry Suso, one of the medieval Rhineland mystics and a disciple of Meister Eckhart also writes of "An eternal nothing and its coming to be in time" (318). Nor is it unheard of to employ nihilistic terms in describing this negative approach to God. In Nihilism and Modernism, for instance, Shane Weller refers to Gershom Scholem, a scholar of Kabbalah and Jewish mysticism who sees forms of "religious nihilism" and "mystical nihilism" in the work of Franz Kafka (111-112). Scholem, referring to a form of Jewish mystical nihilism, writes, "“The Torah [...] is the seed corn of Salvation, and just as the seed-corn must rot in the earth in order to sprout and bear fruit, the Torah must be subverted in order to appear in its true Messianic glory"" (112). There is thus an ambiguity in the "nothing" to which Motes converts, between a strictly humanist nihilism and a mystical nihilism. This ambiguity represents the fundamental ambiguity of the text and is the main source of the "cross-pressure" both Motes and the reader must face. 
Hazel's reason for going to Taulkinham in the first place raises the question of this fundamental ambiguity. On the train, when questioned by Mrs. Wally Bee Hitchcock as to his reasons for going to Taulkinham, Hazel replies, “'Don't know nobody there, but I'm going to do some things [...] I'm going to do some things I never have done before"' ( $\mathrm{O}^{\prime}$ Connor $W B$ 5). Some readers may assume that he is referring to preaching the "Church without Christ". This, however, is not the case. Though he is described as looking like a preacher and mistaken for one by a taxi driver, he doesn't decide to preach until after having met Asa and Sabbath Hawks. By "things" Hazel is referring to "sins". He is going to Taulkinham in order to "sin". Thus, his first action in the city is to get the name and address of Mrs. Leora Watts, an obese and gap-toothed prostitute, off the bathroom wall and spend the night with her. Later we learn that this was "the first time he had slept with any woman" (33). Hazel's purpose in doing so, however, is to seek Truth rather than pleasure. In other words, rather than wishing to disprove the reality of sin in order to give himself license, he commits so-called sins in order to disprove their ultimate reality. This is plainly evident in his later intention to seduce Sabbath: "He felt that he should have a woman, not for the sake of the pleasure in her, but to prove that he didn't believe in sin since he practiced what was called it" (62). This attempt to disprove the reality of sin can obviously represent a purely humanist agenda, but not necessarily so. It can also represent a drive to discern the deeper mystery of sin, a groping in the dark for the presence of God. Gershom Scholem, the scholar of Jewish mysticism, explains an eighteenth-century form of "mystical nihilism" as actually entailing a descent into sin, writing “" $[w]$ e must all descend into the realm of evil in order to vanquish it from within"” (Weller 112). Thus in Hazel's descent into "sin" there is an ambiguity between a 
strictly humanist attack on Judeo-Christian morals and a descent into the crucible of a deeper mystery, the "cross-pressure" from this latter possibility being implicit in the very morals which are under attack.

Thus, the "nothing" to which Hazel converts casts its ambiguous shadow on the question of Judeo-Christian morals: are they ultimately meaningless, as seen in the context of a humanist nihilism, or do they represent a visible manifestation of some deeper, unfathomable enigma, as seen in the context of a mystical nihilism? While Hazel does arrive in Taulkinham as one seeking the Truth, his initial bias is certainly in favor of the former. This can be accounted for in various ways. Though stemming from his childhood, Hazel's general unease concerning the "wild, ragged figure" of Jesus and the uncertainty of faith is one factor. In this sense, Hazel would prefer the truth of a humanist nihilism, though, his integrity, which O'Connor identifies as his chief virtue (HOB 89), would never allow him to settle for self-deception. Another factor, and perhaps the main one, is the influence of the secular age in which he dwells and the positivist Zeitgeist with which it approaches questions of truth. Thus, when Hazel decides upon starting the “Church Without Christ," he rhetorically questions a gathered crowd, “"Don't I know what exists and what don't $[\ldots]$ don't I have eyes in my head'" (O'Connor WB 31). Later, telling a gas station attendant about his church, he instructs him that it is "not right to believe anything you couldn't see or hold in your hands or test with your teeth" (116). This positivist approach is also evident in many of his sermons, as when he says, "“there was no Fall because there was nothing to fall from and no Redemption because there was no Fall and no Judgment because there wasn't the first two"' (59). The statement "there was nothing to fall from" reveals an inability to connect morality and sin to something 
unseen, to a no-thing beyond the scope of observation. In another sermon, he asks the crowd, "“Where in your time and your body has Jesus redeemed you? [..] Show me where because I don't see the place. If there was a place where Jesus had redeemed you that would be the place for you to be, but which of you can find it?'" (93). Thus, Hazel is initially driven towards a humanist nihilism.

This leaning towards humanism becomes all the more evident in Hazel's call for a “"new jesus"” (80). With a crowd gathered around him one night, he implores, "“The Church Without Christ don't have a Jesus but it needs one! It needs a new jesus! It needs one that's all man, without blood to waste"” (80). Hazel is here rhetorically invoking a new purely human jesus to be the face of his church, a church in which " "the blind don't see and the lame don't walk and what's dead stays that way"' (59). The obvious irony in this "new jesus" is that, generally, those who invoke a purely human jesus do so on the basis of morality, seeing in him a good moral teacher, something like a Jewish Socrates, whereas Motes has repudiated humanist morality and makes a point to "sin" on principle. Thus, he cannot be invoking such a moral jesus. But what is left of Jesus once his divinity and his moral example have been negated, once he is simply human all too human? What is left, Enoch Emery reveals, is naught but a shriveled and shrunken anthropological specimen, a taxidermied mascot for the doomed.

Enoch Emery is the strangest character in the book by far. He is eighteen years old and works in Taulkinham at the city zoo. He possesses what he refers to as "wise blood" (44) which always instructs him as to what he must do. For some time prior to meeting Hazel Motes his blood had been guiding him to the museum on the zoo grounds where in a glass display case there slumbered "a dead shriveled-up part-nigger dwarf” (99). 
Initially Enoch is uncertain as to the meaning of this mysterious revelation, his blood only instructing him on a need-to-know-basis. Eventually his blood tells him that he is to show this "mystery" to Hazel Motes, but when he does so the latter is unreceptive. It is only when Enoch hears Hazel preaching about the "new jesus" that the true meaning of his blood's revelation dawns on him. Henceforth, Enoch disguises himself and absconds with the "new jesus," stashing him for awhile in a makeshift tabernacle in his rooming house. When he delivers the "new jesus" to Motes, the latter is sleeping and Sabbath receives the "package" (104). When she reveals it to Motes later on, the latter "snatched the shriveled body and threw it against the wall," whereby, "[t]he head popped and the trash inside sprayed out in a little cloud of dust" (106). The meaning of this is clear. The "new jesus," purely human and thus dead for millennia, is a bag of dust, preserved uselessly for posterity, for generation upon generation who are likewise doomed. For, with Jesus' Godhood repudiated, the possible theosis of humanity is a moot point, and thus in the "new jesus" is reflected the "new man," who, biblically speaking, is the "old man," aka Adam, the primordial dirt bag (Gen 3:19).

Hazel's violent rejection of the coming of this "new jesus" is clearly indicative of the "cross-pressure" assailing him as he seeks the Truth. On the one hand, he is pulled towards a humanist world view, while on the other he is utterly revolted when confronted with the full implications of that world view. This ambivalence is also evident in his relation with Sabbath Lilly. One night in Hazel's room, Sabbath says, “"Listen [...] from the minute I set eyes on you I said to myself, that's what I got to have, just give me some of him! [...] That innocent look don't hide a thing, he's just pure filthy right down to the guts, like me. The only difference is I like being that way and he don't'" (O'Connor WB 
95). She then says, "'I can teach you how to like it. Don't you want to learn how to like it?"”, to which he replies, "'Yeah [...] I want to"” (95-96). Hazel is thus disgusted with the very amoral humanism he is preaching. In other words, the morals he is repudiating, as though rooted to something deep within himself, continue to ring true.

This inner "cross-pressure" is given external expression just prior to Hazel's blinding himself in a strange act of faith. While he is trying to leave town in his "rat colored" automobile, a patrolman pulls him over. When asked why, the patrolman states, "II just don't like your face"' (117). After Hazel gives the patrolman some lip, the latter asks Hazel to drive to the top of a hill and point his car toward the embankment, saying, "“I want you to see the view from up there, puttiest view you ever did see"” (117). After Hazel follows the patrolman's instructions and gets out of his car, the latter pushes the car over the embankment: "The car landed on its top, with the three wheels that stayed on, spinning. The motor bounced out and rolled some distance away and various odd pieces scattered this way and that" (118). This clearly must be read as a symbolic act in which a representative of the Law destroys that which justifies a purely humanist existence. Like the people in the market place Hazel could disguise the emptiness of the world view he was promoting through consumer materialism. This is the meaning of his statement that "No one with a good car needs to be justified"”. The obverse of this statement is, of course, that without a good car one does need to be justified, and thus Hazel is driven to his act of faith.

John J. Han views the destruction of Hazel's car as the point of his conversion. He writes, "Hazel has a moment of spiritual awakening after his old car, which served as his 
mobile church, is destroyed by a patrolman" (196). This belief, however, is clearly not substantiated by the text. Hazel's reaction reads as follows:

Haze stood for a few minutes, looking over at the scene. His face seemed to reflect the entire distance across the clearing and on beyond, the entire distance that extended from his eyes to the blank gray sky that went on, depth after depth, into space. His knees bent under him and he sat down on the edge of the embankement with his feet hanging over (O’Connor $W B$ 118).

First of all, since the narrator goes to the trouble of describing Hazel's knees as being "bent under him," it must be so as to contrast the latter's seated position with the typical position of a sudden conversion which would be to fall onto one's knees. Furthermore, a few lines from this, Hazel is described as being "concentrated on space" (118). In other words, Hazel is concentrated on nothing. The car, the product, which obscured the unadorned vision of this nothing lies in a pile of wreckage, forcing Hazel into a state of contemplation. Whether the nothing he sees is the no-thing of the One or the nothingness of positivist humanism is still a matter of ambiguity for both Hazel and the reader. Clearly no such conversion has occurred, and any act of faith which follows is an act of faith in nihilism.

Directly following this episode with the patrolman, Hazel walks back into town, buys a bucket, some quick lime, and returns to his rooming house. When his landlady sees him mixing the quick lime with water from a spigot, she asks, "'What you going to do with that, Mr. Motes,"” to which he replies “"Blind myself”" (119). Hazel does then blind himself in a violent act of faith which contrasts with the failure of Asa Hawks to do the 
same. Critical interpretations of this act abound. Henry T. Edmondson III writes that "This act signifies Hazel's conversion" (58 my emphasis). While both Edmondson and Han seem so certain that Hazel undergoes a definite conversion, this isn't the case. If Hazel does arrive at a union with God, which is ultimately left ambiguous, it is not through a positive conversion, but through what Brainard Cheney refers to as “"negat[ing] his way back to the cross"” (36 Edmondson). ${ }^{1}$ Christ's cross and the salvation to which it leads would thus be built into the very fabric of reality rather than being an abstraction in which one must, first and foremost, believe. Of course, believing in the abstraction would perhaps make it easier to access the reality, but it would by no means be necessary. Another interpretation, offered by Marshall Gentry, reads as follows: "The loss of the eyes in Wise Blood is of course a form of suicide, but it is also specifically a castration, a rejection of sexual contact" (133). While for all critics since Freud it may be tempting and convenient to bring Oedipus to bear on close readings of texts, in this case it is not appropriate. It is true that at the time of Wise Blood's composition, O'Connor was living with Robert Fitzgerald who was translating Oedipus Rex and the rest of Sophocles' Theban cycle. Nonetheless, besides the superficial similarities, there is no connection between Oedipus and Hazel Motes. O'Connor attests to this in one of her letters, writing, "Haze Motes is not an Oedipus figure but there are the obvious resemblances" ( $H O B$ 68). What is especially far-fetched, however, is Gentry's attributing a motive of sexual asceticism to Motes's act of self-mutilation when Motes's every sexual act is committed to further his principles rather than gratify his appetite. The true import of Hazel's act is simply that where Hawks failed to blind

\footnotetext{
${ }^{1}$ Oddly enough Edmondson quotes Cheney in this regard while at the same time arguing in favor of a positive conversion. He clearly does not understand Cheney's meaning.
} 
himself in order to justify his belief, Hazel succeeds in blinding himself in order to justify his unbelief. This clearly recalls Nietzsche's description of the nihilist in The Gay Science as one who "turn[s] his unbelief into a new belief, a purpose, a martyrdom" (286).

While Hazel's faith is in many ways antithetical to what is generally regarded as such, it must nonetheless be distinguished as faith. According to Paul Tillich, a twentieth century protestant theologian with whom O'Connor was quite familiar, "Faith is the state of being ultimately concerned" (1). In one of her letters, O'Connor reveals her concurrence with this understanding of faith, writing, "The only concern, so far as I see it, is what Tillich calls the "ultimate concern"” (HOB 221). While the nihilistic indifference of the market place is indeed antithetical to faith so defined, the nihilism embodied by Hazel Motes is not so. Motes is, without question, ultimately concerned, and the object of his concern is Truth. This is revealed again and again. For instance, after encountering the gospel hustler, Hoover Shoats, Hazel contemptuously tells him, “'You ain't true"” (WB 88). Then, after running over Shoats's hired "Prophet," Hazel tells the dying man, “'Two things I can't stand $[\ldots]$ - a man that ain't true and one that mocks what is" (115). Finally, after Sabbath Lilly accuses him of harboring a secret yearning for Jesus, Motes says, “I don't want nothing but the truth"” (107). Thus the unbelief he seeks to justify is simply the extent of truth that is apparent to the eyes of positivism with which he sees the world.

The other way in which this act represents an act of faith revolves around the symbolic significance of blindness. In Wise Blood, blindness is a symbol for the darkness of religious faith which penetrates beyond sense experience. From this perspective, faith is 
the effect of Hazel's act rather than its cause. In other words, as an ultimate concern for truth, faith is the cause of his act, a cause which leads to the effect of a deeper penetrating gaze and a liberation from the near sightedness of positivism. He now sees with the eyes of faith. In other words, through blinding himself, Hazel has removed the "motes" from his eyes and escaped the positivistic "haze" that had been enshrouding him. This is the meaning of certain statements Motes makes to his landlady, such as when she questions his reasons for performing certain ascetic acts and he responds, "'Mind your business [...] You can't see"” (125). Referring to his blindness, he also tells her, "'If there's no bottom in your eyes, they hold more"" (126). Thus, in his blindness Hazel can see beyond the surface of things towards the ultimate ground of good and evil.

As previously mentioned, the depth of vision Hazel acquires through his violent act of faith causes him to adopt certain ascetic practices which he integrates into a life of contemplation. Thus, when he is not busy "doing nothing" (122), he spends much of his time walking to and fro in his room or in the surrounding neighborhood, his shoes filled with rocks and broken glass. While this practice is similar to one Hazel performed as a child, there is a major difference. As a child, Hazel had to atone for what he had seen. After returning from a carnival where he was given access to an adult exhibit which featured a naked lady in a coffin, he hid from his mother's gaze behind a tree. The latter, clearly of a puritanical bent of mind in her black dresses which "were longer than other women's," discerned that something was amiss and demanded of the child, "What you seen?'" (35). The focus is thus on a specific moral infraction which, though followed by a “nameless unplaced guilt" indicative of original sin, limits Hazel's religious vision. In his 
blindness, conversely, Hazel can discern how this "nameless unplaced guilt" has sundered him from the reality of God.

Besides walking on rocks and glass, Hazel also wears barbed wire around his chest. When his horrified landlady asks why he does such things, he replies, "I'm not clean"” (127). It is thus clearly evident that a drastic change has occurred in Hazel's selfunderstanding. Whereas throughout his ministry he often proclaimed, “'I AM clean," the blasphemous appropriation of the biblical "I AM" underlying the strictly humanist measure of morality, he now sees in himself reason for atonement. Thus, when his landlady asks, “"what do you walk on rocks for,” Hazel answers, “"To pay”” (125). When asked “'for what?”, he replies, “'It don't make any difference for what [...] I'm paying"' (125). This last statement is very significant in that it reveals that Motes still refuses to confess faith in Jesus Christ. His quest for Truth has, however, led him to a participation in what could be called the redemptive suffering of Christ. Thus Christ's statement, "I am the way and the truth and the life" (John 14:6) finds expression through Hazel Motes in a non-confessional manner. This is ultimately what Cheney means by "negat[ing] his way to the cross". What Hazel believes in is still nothing, but it is the mystical no-thing, the bottomless abyss of God, rather than the absurd nothingness of morally relative humanism. Thus Hazel has overcome the "cross-pressure" which has assailed him throughout the text. In other words, the "cross-pressure" of nihilism is itself overcome by nihilism, making Hazel the "perfect nihilist" in the Nietzschean sense, but in contrast to the latter's overcoming, Hazel's overcoming incorporates the values of good and evil in an infinite beyond. 
Due to the fact that Hazel's resolution takes place behind the veil of blindness, the reader is ultimately left "cross-pressured". In other words, all discussion as to the spiritual state of Hazel Motes is conjecture and cannot be anything more. The depth of vision, the mystery behind the mutilated eyes, is only ever hinted at and suggested, both by Motes, as well as his landlady, whose perspective takes up much of the last chapter. Seeing Motes through her eyes means seeing him through the eyes of humanism which means seeing him through the positivist eyes of a secular age. We read, "She was not religious or morbid, for which every day she thanked her stars" (119). When she catches Hazel with barbed wire wrapped around his chest, she says, “'it's not normal. It's like one of them gory stories, it's something that people have quit doing-like boiling in oil or being a saint or walling up cats" (127 my emphasis). Finally, sitting on the porch one day with Hazel, she says, “'I'm as good [...] not believing in Jesus as a many a one that does"' (125). Thus, from her perspective of morally relative humanism, Hazel represents a source of "cross-pressure", which becomes the reader's by proxy.

To the landlady, Hazel has "the look of seeing something" (120). She asks herself, "Why had he destroyed his eyes and saved himself unless he had some plan, unless he saw something that he couldn't get without being blind to everything else?" (122). This thought begins to occupy her more and more:

She could not make up her mind what would be inside his head and what out. She thought of her own head as a switchbox where she controlled from; but with him, she could only imagine the outside in, the whole black world in his head and his head bigger than the world, his head big enough to include the sky and planets and whatever was or had been or 
or would be. [...] She imagined it was like you were walking in a tunnel and all you could see was a pin point of light; she couldn't think of it at all without that. She saw it as some kind of star, like the star on Christmas cards. She saw him going backwards to Bethlehem and she had to laugh (123).

Here what the landlady and the reader are faced with is the possibility of internal transcendence as opposed to the external transcendence suggested by Tarwater's vision in The Violent Bear It Away. Both express a mode of experience beyond the verifiable scope of positivism, though in very different ways. In The Violent Bear It Away, Tarwater's outward vision is undermined by various factors specific to his person. In Wise Blood there is no such outward vision, but rather, the suggestion of an inward vision, of the endless vista of the via negativa. ${ }^{2}$

The book ends with Hazel laid out on his landlady's bed after having been returned to the rooming house by two police officers who found him lying in a ditch. The landlady is initially unaware that he is dead, having died en route in police custody:

She had never observed his face more composed. [...] The outline of a skull was plain under his skin and the deep burned eye sockets seemed to lead into the dark tunnel where he had disappeared. She leaned closer and closer to his face, looking deep into them, trying to see how she had been cheated or what had cheated her, but she couldn't see anything. She shut her eyes and saw the pin point of light but so far away that she could

\footnotetext{
${ }^{2}$ The apophatic, or negative, approach to God.
} 
not hold it steady in her mind. She felt as if she were blocked at the entrance to something. She sat staring with her eyes shut, into his eyes, and felt as if she had finally got to the beginning of something she couldn't begin, and she saw him moving farther and farther away, farther and farther into the darkness until he was the pin point of light (131).

From her humanist perspective, the landlady is simply confronted with a corpse and yet she senses the presence of a deeper mystery which she cannot penetrate but in the darkness of faith. Her predicament, which is that of the reader's, is the one Motes faced when confronted with the "new jesus". Is the essence of man "dust" and "trash" or does his visible reality conceal a mystery that can only be known in the darkness of unknowing? In shutting her eyes to look into his, the landlady is straining towards the cloud of unknowing. But it is precisely there that the narrative, and all narrative, must end.

That Wise Blood so clearly tends "toward mystery" obviously qualifies it as “grotesque realism" as defined by O'Connor. And yet, it also must be regarded as a fantastic text in that both characters and readers alike are left hesitating before the possibility of divine mystery. While the main mystery of the text centers on the possibility of internal transcendence and thus does not involve a potentially supernatural spectacle of the nature of Tarwater's vision in The Violent Bear It Away, there are instances where characters and reader alike face the possibility of manifest supernatural agency. For instance, the fact that both a highway sign and the fraudulent Asa Hawks accuse Motes of "fornication and blasphemy," two sins of which he is actually guilty, suggests that God may be speaking through these agents. There is also the cloud which is 
described as a "large blinding white one with curls and a beard" (66) which precedes Hazel's car as he is driving in the country, analogous to the cloud of God which led the Israelites out of Egypt into the desert (Ex 13:21). When Hazel is returning to the city, the cloud transforms into "a bird with long thin wings [...] disappearing in the opposite direction" (O’Connor WB 72). This clearly evokes images of the Holy Spirit as dove and God as Trinity. While Hazel may not be aware of this latter manifestation, the reader most certainly is.

Thus, in Wise Blood, as in The Violent Bear It Away, the genres of grotesque realism and the fantastic seamlessly coalesce so that characters and reader alike hesitate before the possibility of a divine mystery at the heart of reality, a mystery that cannot be measured or verified, but which calls for a response of faith. This possibility undermines the fundamental assumptions of a humanist positivism so that any adherence to such, itself, takes on the aspect of faith. The text thus reflects the "open space" of a secular age and the "cross pressure" which assails it, in this case through the uncanny atmosphere of nihilism. 
Conclusion: Cross-Pressure and the Pressure of the Cross

In an essay entitled, "The Teaching of Literature," O'Connor writes, "[i]t is the business of fiction to embody mystery through manners" and, "[t]he result of the proper study of a novel should be contemplation of the mystery embodied in it" $(124,129)$. Here O'Connor is not referring to a specifically "Christian" mystery which could not possibly be the "business" of all fiction, but of a mystery at the very heart of reality which should be reflected in all good fiction. With this central concern for "mystery" it is perhaps somewhat paradoxical that so many of the questions which O'Connor's fiction leaves the reader contemplating find answers in her correspondence and non-fictional work. For instance, in a letter to “A," dated November 10, 1955, O'Connor writes, "All H. Motes had to sacrifice was his sight but then (you are right) he was a mystic and he did it" (HOB 116 my emphasis). Thus the central ambiguity embodied in the character of Hazel Motes is clarified. Similarly, in a letter dated December 28, 1956, O’Connor writes, "In my novel I have a child — the schoolteacher's boy—whom I aim to have a kind of Christ image" (HOB 191 my emphasis). Thus O'Connor reveals the truth regarding Bishop's mysterious nature as well. It can perhaps be argued that these statements, being part of O’Connor's private correspondence, were never intended for public consumption. But then why, in an introductory note to the 1962 edition of Wise Blood, did O'Connor characterize it as "a comic novel about a Christian malgre lui" (MM 114), meaning, one who finds Christ despite himself? In doing so, it seems that the preservation of mystery in the novel is ultimately thwarted by the positing of a definite underlying Christian metaphysics. It is true that this introduction was included in an edition marking Wise 
Blood's tenth year. Thus it is quite possible that O'Connor was driven to such measures by the many "misreadings" of the novel, previously alluded to by Jordan Cofer. In fact, in a letter dated May 18, 1955, just prior to a television appearance, O’Connor writes, “[e]verybody who has read Wise Blood thinks I'm a hillbilly nihilist, whereas I would like to create the impression over the television that I'm a hillbilly Thomist" $(H O B 81)$. The question O'Connor scholars are left to answer is how O'Connor's fictional vision can be so ambiguous while her professed beliefs and intentions are so unambiguously clear?

O'Connor was well aware of the age for which she was writing. In "The Teaching of Literature," she writes, "mystery is a great embarrassment to the modern mind" (124). Furthermore, in "Some Aspects of the Grotesque in Southern Fiction," she writes, "[s]ince the $18^{\text {th }}$ century, the popular spirit of each succeeding age has tended more and more to the view that the ills and mysteries of life will eventually fall before the scientific advances of man" (815). One must only look as far as Rayber's positivist rationalization of religion and the mystery it presupposes, or to Hazel Motes's approach to Truth, to see this spirit incarnated in her characters. Though it is, perhaps, the Misfit, in "A Good Man Is Hard to Find," who best sums up this positivist Zeitgeist and the predicament it faces concerning matters of faith. Talking to the "grandmother" about the possibility of Jesus' incarnation and the resurrection of the dead he says, "'If He did what He said, then it's nothing for you to do but thow away everything and follow Him, and if He didn't, then it's nothing for you to do but enjoy the few minutes you got left the best way you can"” (152). Here we clearly see the "cross-pressure" of two opposing world views. But it is what he says next that reveals the criteria for truth that the spirit of the age has adopted. 
After the grandmother suggests, "“Maybe He didn't raise the dead," the Misfit responds by saying, "“I wasn't there so I can't say He didn't [...] I wisht I had of been there [...] if I had of been there I would of known and I wouldn't be like I am now" (152). In other words, if he had been able to observe Christ's reported miracles he would be able to believe in their veracity and thus escape the disorientation of "cross-pressure" assailing him. Of course, there are examples of this same attitude present in the gospels. Thomas, one of Jesus' disciples, responded to the news of the risen Christ as follows: "'Unless I see the mark of the nails in his hands and put my finger into the nailmarks and put my hand into his side, I will not believe" (John 20:25). There is thus a striking affinity between the Misfit's and Thomas's ultimatum. Though, as a Jew who likely did believe in a mysterious and transcendent God, it was probably the fact of such awesome power being incarnated in man and appearing as such that confounded Thomas. The Misfit, on the other hand, as a son of a secular age, has an a priori skepticism regarding all things purportedly divine and outside the scope of scientific observation. It is mystery itself which confounds the Misfit.

Like anyone with a prophetic calling, O'Connor cannot accept the terms of the age. In other words, she must depict the form mystery takes in a secular age while keeping that mystery intact. Anything less would be vulgar didacticism. In a letter dated Aug 28, 1955, O’Connor writes, "If I hadn't had the Church to fight it with or to tell me the necessity of fighting it, I would be the stinkingest logical positivist you ever saw right now. With such a current to write against, the result almost has to be negative" (HOB 97). Here she is not only acknowledging the "cross-pressure" she experiences due to the positivist spirit of the age clashing with the spirit of the Church, but she is also drawing 
attention to the negative form mystery must assume in her fiction. In The Violent Bear It Away, this negativity is apparent in the "violence" and "madness" with which mystery must be met, those radical responses which maintain the text's ambiguity and the "open space" for hesitation. In Wise Blood, negativity takes the form of an ambiguous nothingness which can only be penetrated by the eyes of faith. Thus, while O'Connor may be a grotesque realist capable of discerning a hidden depth to reality, she must self consciously render her vision "fantastic" through the "violence," "madness," and "nothingness" of religious faith in order to bring that depth to the surface of an age steeped in logical positivism. In other words, in order to depict divine mystery in a secular age it must be rendered fantastic.

While The Violent Bear It Away associates the act of religious faith with "violence" and "madness," and Wise Blood associates the object of that faith with "nothingness," it should not be assumed that in order to resolve the ambiguity of the novels without resorting to O'Connor's extra-textual commentaries one need take a leap into absurdity. In one of her letters, after outlining certain central Catholic dogmas, O'Connor writes, “To believe all this, I don't take a leap into the absurd. I find it reasonable to believe, even though these beliefs are beyond reason" ( $H O B$ 479). In this statement there is a definite sense that what one believes should, to a certain extent, be reasonable. Thus, in order to resolve the ambiguity of both texts, the reader can and should rely on the light of reason to go some of the way. For instance, the reader can reason that in both the case of Rayber and Tarwater, the "cross-pressure" coming from the pole of belief seems forced upon them despite themselves and therefore it must represent the true reality. Thus, despite Tarwater's intention to only drown Bishop, he baptizes him. And despite 
Rayber's desire to ignore the "horrifying love" triggered by Bishop, it overcomes him. It could be reasoned that there is a divine will at play here, overpowering the self-will of the respective characters. It could, however, also be reasoned that Tarwater's drive to baptize Bishop stems from some unconscious impulse instilled in him as a child. And it could be reasoned in the manner of Freud that Rayber's horrifying love represents a case of primary narcissism. The reader can also look at which character's life represents a more fulfilling vision. Certainly the emptiness and numbness with which Rayber meets his son's death does not seem the perfect picture of human fulfillment. There is also the definite statement that he has staved off the madness of his uncle "at the cost of a full life". Thus at first glance it would seem that Tarwater represents a life more fulfilled. And yet, what can Tarwater's future hold but ignominious dereliction? Perhaps the best line of reasoning follows Tarwater's hunger for the Bread of Life, a hunger he vehemently denies for much of the book, but which becomes all consuming and insatiate in the presence of all worldly fare. Perhaps this hunger represents the natural desire for God which Thomas Aquinas expresses when he writes, "It is evident that naught can lull man's will, save the universal good. This is to be found, not in any creature, but in God alone” (ST I-II Q.2 Art.8). From this perspective it would be Rayber who, through stifling and denying that desire through a humanist asceticism, takes the absurd leap, whereas Tarwater follows his natural desire to its proper and reasonable end. Tarwater's "madness" is thus more reasonable than Rayber's cherished "reason".

In the case of Hazel Motes, one could reason that the various signs which confront him, such as a phony preacher rightfully accusing him of sins of which he is guilty, and a painted roadside sign doing the same, represent the voice of God speaking His Truth 
through people and things. Yet these occurrences could also be purely coincidental. One could reason that the cloud that hovers above his car is a divine manifestation similar to that which led the Israelites through the desert of Sinai. Yet, with the possibility of a nihilistic narrator positing false transcendental values, any meaning attributed to a cloud in the sky becomes dubious. One could reason that the patrolman who destroys Hazel's car is a divine emissary of the moral law come to destroy the symbol of Hazel's humanistic justification. Then again, he may just be an irate cop who Hazel pushes too far. Perhaps the best line of reasoning follows Hazel's desire for Truth. For he not only blinds himself for the sake of Truth, but kills a man who he views as untruthful. Hazel thus seeks the Truth at all cost, even that of damnation. Where this quest ultimately leads him is to a place of atonement and contemplation where he expresses an urgency to "'go on where I'm going'" (O'Connor $W B$ 131), as though that Truth which sets one free was finally within sight now that he was blind to all the world.

These are some ways in which it is possible for the reader to have faith in both the "impossible vision of a world transfigured" (401) presented in The Violent Bear It Away as well as in the inner light of Truth hinted at in Wise Blood. In both cases, that which Christian dogma professes is revealed as part of the fabric of reality discernible by the eyes of religious faith rather than a mere abstract belief system demanding intellectual assent and submission. Thus, through O'Connor's fictional vision, Taylor's term, itself, takes on an ambiguous meaning: the "cross-pressure" of a secular age becomes the pressure of the Cross. 
Works Cited

Aquinas, Thomas. The Summa Theologica. Trans. Fathers of the English Dominican Province. Vol. 2. Indiana: Christian Classics, 1948. Print

Ciuba, Gary M. "NOT HIS SON': Violent Kinship and the Spirit of Adoption in The Violent Bear It Away." Dark Faith. Ed. Susan Srigley. Indiana: University of Notre Dame Press, 2012.57-86.Print.

Cofer, Jordan. 'Flannery \& Franz: Tracing the Kafkaesque Influences on O'Connor's Wise Blood." Wise Blood: A Re-consideration. Ed. John J. Han. New York: Rodopi, 2011. 161-179. Print.

Desmond, John F. “The Lost Childhood of George Rayber.” Dark Faith. Ed. Susan Srigley, Indiana: University of Notre Dame Press, 2012. 35-56. Print.

Donahoo, Robert. 'Everything That Rises Does Not Converge: The State of O'Connor Studies."Flannery O'Connor in the Age of Terrorism. Ed. Avis Hewitt and Robert Donahoo. Knoxville: University of Tennessee Press, 2010. 241-258. Print.

Edmondson, Henry T. Return to Good and Evil. New York: Lexington Books, 2002. Print.

Fraser, Giles. Redeeming Nietzsche. New York: Routledge, 2002. Print.

Freud, Sigmund. "Civilization and Its Discontents." The Freud Reader. Ed. Peter Gay. New York: W.W. Norton \& Co., 1989. 722-772. Print.

Freud, Sigmund. "Obsessive Actions and Religious Practices." The Freud Reader. Ed. Peter Gay. New York: W.W. Norton \& Co., 1989. 429-436. Print.

Freud, Sigmund. "The Question of a Weltanschauung." The Freud Reader. Ed. Peter Gay. New York: W.W. Norton \& Co., 1989. 783-796. Print.

Gentry, Marshall Bruce. Flannery O'Connor's Religion of the Grotesque. Jackson: University of Mississippi Press, 1986. Print.

Giannone, Richard. Flannery O'Connor, Hermit Novelist. Chicago: University of Illinois Press, 2000. Print.

Han, John. J. "A Roman Catholic Response to Nihilism and Protestantism: Wise Blood as an Anti-Kafkaesque Novel." Wise Blood: A Re-consideration. Ed. John J. Han. New York: Rodopi, 2011. 181-205. Print. 
Heidegger, Martin. "The Age of the World Picture.” The Heidegger Reader. Ed. Gunter

Figal.Trans. Jerome Veith. Indianapolis: Indiana University Press, 2007. 207-223.

Print.

Hungerford, Amy. Postmodern Belief. Princeton: Princeton University Press, 2010. Print.

Lake, Christina Bieber. "The Violence of Technique and the Technique of Violence."

Flannery O'Connor in the Age of Terrorism. Ed. Avis Hewitt and Robert Donahoo. Knoxville: University of Tennessee Press, 2010. 25-39. Print.

Martin, Carter W. The True Country. Vanderbilt University Press, 1969. Print.

Martin, Karl E. "Suffering Violence in the Kingdom of Heaven: The Violent Bear It Away. " Dark Faith. Ed. Susan Srigley. Indiana: University of Notre Dame Press, 2012. 157-184. Print.

McClure, John A. Partial Faiths. Athens: University of Georgia Press, 2007. Print.

Monroe, William. "Confinement and Violence, Flannery and Foucault." Flannery O'Connor in the Age of Terrorism. Ed. Avis Hewitt and Robert Donahoo. Knoxville: University of Tennessee Press, 2010. 213-230. Print.

Muller, Gilbert H. Nightmares and Visions: Flannery O'Connor and the Catholic Grotesque. Athens: University of Georgia Press, 1972. Print.

New American Bible for Catholics. New York: American Bible Society, 1991. Print.

Nietzsche, Friedrich. The Gay Science. Trans. Walter Kauffman. New York: Vintage Books, 1974. Print.

Nietzsche, Friedrich. The Will to Power. Ed. Walter Kauffman. Trans. Walter Kauffman. New York: Random House, 1967. Print.

O'Connor, Flannery. "A Good Man is Hard to Find." Collected Works. New York: The Library Of America, 1988. 137-153. Print.

O'Connor, Flannery. Habit of Being. Ed. Sally Fitzgerald. New York: Noonday Press, 1979. Print.

O’Connor, Flannery. Mystery and Manners. Ed. Sally and Robert Fitzgerald. New York: Farrar, Strauss \& Giroux, 1957. Print.

O'Connor, Flannery. "Some Aspects of the Grotesque in Southern Fiction." Collected Works. New York: The Library of America, 1988. 813-821. 
O’Connor, Flannery. “The Teaching of Literature.” Mystery and Manners. Ed. Sally and Robert Fitzgerald. New York: Farrar, Strauss \& Giroux, 1957. 121-134. Print

O'Connor, Flannery. The Violent Bear It Away. Collected Works. New York: The Library Of America, 1988. 329-479. Print.

O’Connor, Flannery. Wise Blood. Collected Works. New York: The Library of America, 1988. 1-131. Print.

Peters, Jason. “Abstraction and Intimacy in Flannery O'Connor's The Violent Bear It Away." Dark Faith. Ed. Susan Srigley. Indiana: University of Notre Dame Press, 2012. 87-103. Print.

Ragen, Brian Abel. A Wreck on the Road to Damascus. Chicago: Loyola University Press, 1989. Print.

Taylor, Charles. A Secular Age. Cambridge, Massachusetts: Belknap Harvard Press, 2007. Print.

Tillich, Paul. Dynamics of Faith. New York: Harper \& Brothers, 1957. Print.

Todorov, Tzvetan. The Fantastic: A Structural Approach to a Literary Genre. Trans. Richard Howard. Cleveland: The Press of Case Western Reserve University, 1973. Print.

Weller, Shane. Modernism and Nihilism. New York: Palgrave Macmillan, 2011. Print.

Wood, Ralph C. Flannery O'Connor and the Christ-Haunted South. Michigan: William B. Eerdmans Publishing Company, 2004. Print.

Zorando, Joseph. "A Becoming Habit: Flannery O'Connor's Fiction of Unknowing." Religion and Literature 29.2 (1997): 27-59. University of Notre Dame. Web. 24 May 2013. 